DARIUSZ K. CHOJECKI

https://orcid.org/0000-0002-6071-7033

Instytut Historyczny Uniwersytetu Szczecińskiego

\title{
POLSCY OPTANCI Z ZAGEĘBIA RUHRY W 1924 ROKU. ASPEKTY DEMOGRAFICZNE
}

Zarys treści: Odbudowie państwa polskiego po I wojnie światowej towarzyszyło wiele przypadków powrotu do kraju. Jeden ze strumieni remigracyjnych tworzyli polscy optanci z Niemiec, którzy na mocy traktatu wersalskiego postanowili przyjąć obywatelstwo polskie. Głównym miejscem wychodźstwa stał się obszar Zagłębia Ruhry. Celem niniejszego artykułu jest przedstawienie struktury demograficznej osób tworzących ową falę migracyjną w jej późnej fazie (1925). Do analizy wykorzystano imienne wykazy optantów, które posłużyły do przeprowadzenia grupowania statystycznego i ukazania przestrzennego rozkładu interesującego nas zjawiska. Badania dotyczyły zbiorowości 1727 osób ujętych w źródle. Oprócz metody agregatywnej i kartograficznej wykorzystano metodę porównawcza, dysponując niezbędnymi danymi dla innych obszarów państwa Prusy. Badania ukazały specyfikę polskich optantów w Zagłębiu Ruhry w odniesieniu do ich rozlokowania przestrzennego, zawodów, feminizacji, typu migrowania, form gospodarstw domowych, dzietności czy antroponimów.

The content outline: The rebuilding of the Polish state after World War I was accompanied by a quantitively significant number of returns to the country. One of the re-emigration streams was created by an influx of Polish optants from Germany, i.e. ethnic Poles who had decided to take up Polish citizenship under the Versailles Treaty. The principal area of emigration was the Ruhr region. The purpose of this paper is to examine the demographic structure of the people who made up this migration stream in its late phase (1925). The analysis is based on lists of optants which were drawn up for the purpose of statistical grouping and showing the optants' spatial distribution. The research concerns a population of 1,727 people included in the source. In addition to aggregate and cartographic methods, the paper also uses the comparative method based on the available data for other areas in the state of Prussia. The research helps describe the population of Polish optants in the Ruhr area in terms of their spatial distribution, professions, feminisation, type of migration, household forms, fertility, and anthroponyms. 
Słowa kluczowe: wychodźstwo, opcja, wybór obywatelstwa polskiego, Zagłębie Ruhry, polski konsulat w Essen, okres międzywojenny, demografia historyczna, struktura

Keywords: emigration, option, choice of Polish citizenship, Ruhr area, Polish consulate in Essen, interwar period, historical demography, structure

\section{Wstęp}

Wkrótce po zakończeniu I wojny światowej obszar państwa polskiego stał się miejscem reemigracji osób, które pragnęły związać swój byt z odrodzoną Rzeczpospolita. Głównymi źródłami tego masowego ruchu ludności były tereny z pokonanych Niemiec i objętej wojną domowa Rosji ${ }^{1}$. W przypadku pierwszego jego trzon stanowiło „młode” wychodźstwo z obszaru Zagłębia Ruhry, składające się zarówno z przybyłych, jak i urodzonych na miejscu osób (drugie i trzecie pokolenie migrantów). Miało ono krótką metrykę , właściwie sięgająca lat siedemdziesiątych XIX stulecia, kiedy to nastapił boom rozwoju przemysłowego, przede wszystkim górniczego i hutniczego, po obu stronach rzeki Emschery, generujący wzrost popytu na pracę ${ }^{3}$, z czego nie omieszkali skorzystać polscy obywatele państwa pruskiego, głównie pochodzący z Wielkopolski. Według danych z grudnia $1910 \mathrm{r}$. westfalsko-nadreński obszar przemysłowy zamieszkiwało już 247 tys. Polaków, w tym 79,5 tys. urodzonych na miejscu i 104,8 tys. w prowincji poznańskiej ${ }^{4}$, nie wspominając już o ludności kaszubskiej czy mazurskiej. Po zakończeniu wojny na fali uniesienia patriotycznego gros polskich wychodźców i ich potomków

${ }^{1}$ W tematykę ruchów migracyjnych na ziemiach polskich wprowadza: C. Leszczyńska, Polish Emigration Abroad. Regional Structure and Streams of Emigration in the Years 1870-1914 and 1918-1939, „Przeszłość Demograficzna Polski” 41, 2019, s. $177-207$.

${ }^{2}$ Por. Z. Keller, Die Fremdsprachige Bevölkerung im Freistaate Preußen, „Zeitschrift des Preußischen Statistischen Landesamts" 66, 1926, s. 182. Autor pracy wskazuje, że w 1861 r. tylko cztery rodziny posługujące się językiem polskim bądź kaszubskim zamieszkiwały obszar rejencji Düsseldorf. Natomiast w rejencji Arnsberg i Münster nie odnotowano w tym czasie żadnej rodziny spełniającej to kryterium. Szerzej na temat rozwoju demograficznego ludności w Nadrenii i Westfalii zob. W. Köllmann, Bevölkerung in der industriellen Revolution, Göttingen 1974, s. 229-249.

${ }^{3}$ Zob. H. Kiesewetter, Industrielle Revolution in Deutschland 1815-1914, Frankfurt am Main 1989, s. 194, 201-203, 228-231 i in.

4 „Statistisches Jahrbuch für den Preußischen Staat” 11, 1913, s. 30-31 (Gebürtigkeit der am 1. Dezember 1910 in den Kreisen des rheinisch-westfälischen Industriegebietes ermittelten Polen [Bisher unveröffentlichtes Material]). 
postanowiło powrócić do ojczystego kraju m.in. w ramach możliwości wyboru obywatelstwa polskiego, tzw. opcji, co przewidywały stosowne, acz rozbieżne regulacje traktatu wersalskiego i traktatu mniejszościowego. Zagadnienia te sa szeroko przedstawione $\mathrm{w}$ literaturze przedmiotu, szczególnie w studiach Mirosława Piotrowskiego (w odniesieniu do polskich optantów) ${ }^{5}$ i Marka Stażewskiego (w kontekście niemieckich optantów) ${ }^{6}$. Ograniczę się zatem do przypomnienia kilku niezbędnych faktów, które pomoga w naświetleniu sytuacji związanej z reemigracja, dając kontekst dla przedstawionych wyników badań. W Zagłębiu Ruhry wnioski o obywatelstwo polskie złożyło blisko 10 tys. osób, co, uwzględniwszy członków rodzin, dawało liczbę ok. 40 tys. osób objętych opcja ${ }^{7}$. Jednakże nie wszyscy optanci zdecydowali się na powrót do Polski. Wynikało to nie tylko z trudnej sytuacji panujaccej w kraju, lecz również z faktu, że stali się oni przedmiotem gry dyplomatycznej prowadzonej przez Rzeczpospolitą Polską i Rzeszę Niemiecka. Jej stawką było „odniemczenie” (niem. Entdeutschung), by użyć sformułowania Hermana Rauschninga, województwa poznańskiego i pomorskiego tudzież, patrząc z perspektywy zachodniego sasiada, zahamowanie odpływu ludności niemieckiej z utraconych obszarów celem prowadzenia szeroko zakrojonej polityki rewindykacyjnej ${ }^{8}$. Dodajmy, że z przyczyn ekonomicznych ani jednemu, ani drugiemu państwu nie zależało specjalnie na przyjęciu u siebie potężnej rzeszy optantów, co też tłumaczy, dlaczego wyznaczona kolejna data, tj. 10 I 1923 r., nie przyniosła przełomu w skutecznym wymuszeniu realizacji opcji, której stan pozostawał obu stronom bliżej nieznany z powodu nieujawnienia wykazów optantów9

Zasadniczym celem artykułu jest przedstawienie w kontekście porównawczym specyfiki późnej (potencjalnej) reemigracji z Zagłębia Ruhry do Polski pod kątem cech demograficznych optantów, z naciskiem na zagadnienia strukturalne. Wśród postawionych pytań badawczych

${ }^{5}$ M. Piotrowski, Reemigracja Polaków z Niemiec, 1918-1939, Lublin 2000; tenże, Wychodźstwo polskie w Zagłębiu Ruhry jako faktor polsko-niemieckiej gry dyplomatycznej, w: Schimanski, Kuzorra i inni. Polacy w Zagtębiu Ruhry 1870/71-1945, red. J. Dahlmann, A.S. Kotowski, Z. Karpus, Toruń 2006, s. 196-223.

${ }^{6}$ M. Stażewski, Opcja ludności niemieckiej $w$ Wielkopolsce $i$ na Pomorzu $w$ latach dwudziestych, „Przegląd Zachodni” 1994, nr 1, s. 31-55; tenże, Przymusowy wyjazd $z$ Polski optantów niemieckich w 1925 roku, „Studia Historica Gedanensia” 5, 2015, s. $95-112$.

${ }^{7}$ M. Piotrowski, Wychodźstwo polskie..., s. 206.

8 Szerzej na temat procesów ludnościowych na ziemiach zachodnich Polski przed i po I wojnie światowej zob. D.K. Chojecki, Population Changes in Polish Western Territories Before and After World War I, „Historická demografie” 44, 2020, nr 1, s. 93-131.

${ }_{9}^{9}$ M. Piotrowski, Wychodźstwo polskie..., s. 207. 
na pierwszy plan wysuwają się następujące: w jakim zakresie można wykorzystać przekaz źródłowy do badań demograficznych?, jak kształtował się rozkład przestrzenny liczby optantów?, kto potencjalnie wiódł prym w reemigracji?, na ile możliwe jest odtworzenie typów gospodarstw domowych optantów?, jakie formy wychodźstwa optantów dominowały, a które były rzadziej reprezentowane?, czy w rodzinach optantów występowały istotne różnice w dzietności?, a jeśli tak, to czym były one uwarunkowane?, wreszcie czy antroponimy optantów odznaczały się jakimiś wzorcami, prawidłowościami? Na podstawie wskazanego katalogu pytań badawczych widać wyraźnie, że zagadnienia polityczne związane z reemigracja, dobrze oświetlone, właściwie nie będą tu rozpatrywane. Moim zamierzeniem jest bowiem ukazanie specyfiki zbiorowości optantów z Zagłębia Ruhry w kontekście jej cech strukturalnych. Badanie zostało przeprowadzone $\mathrm{z}$ wykorzystaniem metod demografii historycznej, zajmującej się charakterystyką minionych populacji czy subpopulacji na podstawie zastanych źródeł, co ważne, nieprzeznaczonych do analiz demograficzno-statystycznych, innymi słowy takich, do których należy podchodzić z dużą dozą krytycyzmu, ale też i szacunku, mając na uwadze stare przysłowie, że „na bezrybiu i rak ryba” ${ }^{10}$. Wspomniano, że analiza będzie miała charakter porównawczy. Jest to możliwe dzięki temu, że zaprezentowano już wyniki badań nad polskimi optantami pochodzącymi z efemerycznej Marchii Granicznej Poznańskie-Prusy Zachodnie, stanowiacej zarazem obszar rejencji pilskiej (tzw. Pogranicze), oraz ze środkowej i zachodniej części Pomorza Zachodniego, tj. rejencji szczecińskiej i stralsundzkiej ${ }^{11}$. Podstawowe wyniki badań nad zbiorowościa optantów z Zagłębia Ruhry są zamieszczone w aneksie (w formie kartograficznej i tabelarycznej).

${ }_{10}$ Zob. uwagi W. Kula, Problemy $i$ metody historii gospodarczej, Warszawa 1963, s. 428-435 (podrozdz. Stan badań. Pesymizm i optymizm poznawczy).

${ }_{11}$ D. Szudra i in., Optanci polscy w prowincji Marchia Graniczna Poznańskie-Prusy Zachodnie $w$ świetle informacji Generalnego Konsulatu RP $w$ Berlinie pochodzacych z przełomu lat 1921 i 1922, „Przegląd Zachodniopomorski” 20 (49), 2005, nr 3, s. 21-33; D. Szudra, Optanci polscy $w$ rejencji stralsundzkiej $w$ świetle informacji Generalnego Konsulatu RP w Berlinie pochodzacych z przełomu lat 1921 i 1922, „Przegląd Zachodniopomorski" 21 (50), 2006, nr 2, s. 45-55; D.K. Chojecki, Optanci polscy w rejencji szczecińskiej $w$ świetle informacji Generalnego Konsulatu RP $w$ Berlinie z przełomu lat 1921 i 1922, „Przeszłość Demograficzna Polski” 34, 2014, s. 89-101. 


\section{Źródła i metody}

Podstawowym źródłem do poznania zagadnień demograficznych zwiazanych z późną emigracją do państwa polskiego w ramach wyboru obywatelstwa są imienne wykazy optantów. Zgodnie z konwencją wiedeńską z 30 VIII 1924 r. zawartą pomiędzy Rzeszą Niemiecką a Rzeczpospolita Polska obie strony zobowiązały się wymienić stosownymi listami osób, których ewidencją na podległym sobie terenie zajęły się władze konsularne. Pełny wykaz polskich optantów w Niemczech został przekazany przez polskie Ministerstwo Spraw Zagranicznych ambasadzie niemieckiej w Warszawie 31 XII $1924 \mathrm{r} .^{12}$, a już pod koniec stycznia $1925 \mathrm{r}$. na podstawie otrzymanych materiałów pruskie Ministerstwo Spraw Wewnętrznych przygotowało okólnik: Registrierung polnischer Optanten - adresowany do prezesów rejencji, landratów i miejscowych władz policyjnych ${ }^{13}$. Zawierał on, obok krótkich wytycznych dla władz, imienny wykaz optantów z siedmiu polskich okręgów konsularnych w Niemczech, $\mathrm{w}$ tym $\mathrm{z}$ interesującego nas: Essen ${ }^{14}$. O istnieniu tego okólnika wspomina Mirosław Piotrowski, który odnalazł go podczas kwerendy w Głównym Archiwum Państwowym w Düsseldorfie ${ }^{15}$. Niezależnie skorzystałem natomiast $\mathrm{z}$ tego samego dokumentu, tyle że zdeponowanego w Archiwum Państwowym w Szczecinie. Wpłyną on do kancelarii rejencji szczecińskiej 31 I 1925 r., co zapewne nieprzypadkowo zbiegło się w czasie $\mathrm{z}$ ratyfikacją tego dnia konwencji wiedeńskiej przez polski sejm.

W odniesieniu do optantów zamieszkujących obszar będący w kompetencji konsulatu w Essen okólnik zawiera indywidualne informacje o 483 wnioskodawcach i 1244 osobach, na które rozciagała się opcja (łącznie 1727). Zestaw danych jest skromny: bieżący numer, nazwisko [wnioskodawcy], imię [wnioskodawcy], zawód [wnioskodawcy], adres [wnioskodawcy] (miejscowość, niekiedy dzielnica, ulica, numer domu), członkowie rodziny, na których rozciąga się opcja (imię żony i jej nazwisko rodowe, imiona dzieci). Jak widać, wymienione cechy mają charakter nominatywny. Imiona pozwalają bez problemu określić

${ }^{12}$ M. Piotrowski, Reemigracja..., s. 356-357. Autor słusznie zwraca uwagę na nieścisłości zawarte w depeszy.

${ }^{13}$ Archiwum Państwowe w Szczecinie (dalej: APSz), Rejencja Szczecińska, Wydział Prezydialny, sygn. 9825, Zur besonderen Vorlage bei Pr.A. Ausschnitt aus Nr. 4/125 Seite Nr. 65 des Ministerialblatt der Preussischen inneren Verwaltung vom 28. Januar 1925: Registrierung polnischer Optanten. RdErl. d. MdJ. v. 22.1.1925-O II 75, k. 112-118.

${ }_{14}$ Pozostałe to: Wrocław, Olsztyn, Kwidzyn, Kolonia, Królewiec i Hamburg.

${ }_{15}$ M. Piotrowski, Reemigracja..., s. 376, przyp. 249: Hauptstaatsarchiv Düsseldorf, Regierung Aachen, Option für Polen, sygn. 18976, k. 66-126. 
płeć, tj. główna, obok wieku, zmienną demograficzna. Dla tego ostatniego niestety nie mamy szczegółowych informacji. Wiadomo tylko, że w dokumencie do kategorii dzieci były zaliczane osoby niepełnoletnie. Dziecko, które ukończyło 18. rok życia ${ }^{16}$, mimo zamieszkiwania z rodzicami lub rodzicem, podejmowało samodzielnie decyzję o opcji, składając stosowne oświadczenie, $\mathrm{z}$ reguły $\mathrm{w}$ polskim przedstawicielstwie konsularnym. Należy także wspomnieć, że źródło sygnalizuje stan cywilny wdowi optantów, zarówno w odniesieniu do mężczyzn, jak i kobiet, co w kontekście starań o zabezpieczenia socjalne nie pozostawało bez znaczenia. Oczywiście interesujący nas wykaz służył zasadniczo dwóm celom: weryfikacji stanu wykonania opcji, a następnie kontroli jej realizacji w zakresie terminów przewidzianych konwencją wiedeńska, która nakazywała optantom nieposiadającym nieruchomości wyjazd z Niemiec albo Polski najpóźniej do 1 VIII 1925 r. (główna fala przymusowej migracji).

Warto zadać pytanie, czy interesujący nas wykaz obejmuje wszystkie osoby, które zgodnie z postanowieniami traktatu wersalskiego i późniejszymi krajowymi rozporządzeniami ministerialnymi złożyły wniosek o skorzystanie z prawa opcji na rzecz państwa polskiego? Nie ulega wątpliwości, że konsulat w Essen, kierowany przez Leona Barciszewskiego, wysoko dotowany i zatrudniający nawet do 80 pracowników etatowych, w opinii ówczesnych funkcjonował wyjątkowo sprawnie, wręcz nowatorsko, a jego pracownicy mieli dobre rozeznanie w terenie ${ }^{17}$. Mirosław Piotrowski wskazuje w swoich badaniach nad reemigracja, że polskie władze konsularne odpowiedzialne za przygotowanie listy podczas roboczego posiedzenia w listopadzie 1924 r. w Poznaniu rozważały wykazanie tylko tych optantów, którzy już przebywali na terenie Polski $^{18}$. Pomysł ten zarzucono, ale postanowiono zataić pewna część osób najbardziej istotnych dla podtrzymywania życia polskiego w Zagłębiu Ruhry. Władzom niemieckim udało się jednak doręczyć zawiadomienia o terminie wykonania opcji także tym osobom, które mimo złożenia

${ }^{16}$ Zob. Ministerstwa Spraw Wewnętrznych i Ministerstwa b. Dzielnicy Pruskiej w porozumieniu z Ministerstwem Spraw Zagranicznych $i$ z Ministerstwem Skarbu w przedmiocie nabycia $i$ utraty obywatelstwa polskiego $w$ myśl art. 91 traktatu między Mocarstwami Sprzymierzonemi i Skojarzonemi a Niemcami, podpisanego $w$ Wersalu dnia 28 czerwca 1919, Dz. U., 1920, nr 57, poz. 358 (rozporządzenie z 13 lipca), art. 5, 12.

${ }^{17}$ W. Skóra, Stużba konsularna Drugiej Rzeczypospolitej. Organizacja, kadry i dziatalność, Toruń 2006, s. 39, 116, 291.

${ }_{18}$ M. Piotrowski, Reemigracja..., s. 356-357. Również niemieckie władze konsularne na wrześniowej naradzie w Poznaniu rozważały zatajenie pewnej liczby optantów niemieckich, którzy złożyli jednostronne oświadczenia, to znaczy tylko przed władzami niemieckimi; M. Stażewski, Przymusowy wyjazd..., s. 101. 
oświadczeń w polskim konsulacie w Essen nie znalazły się w wykazie ujętym w okólniku. Można przypuszczać, że chodziło tu przede wszystkim o osoby, które dokonały opcji dwustronnej (również przed władzami niemieckimi zgodnie z przepisem niemieckiego rozporządzenia ${ }^{19}$ ); nie można też wykluczyć przeprowadzenia rozpoznania wywiadowczego. W efekcie do konsulatu w Essen zgłosiły się 724 „rodziny”" ${ }^{20}$ uprawnione do wyjazdu, czyli, używając bardziej precyzyjnego języka, o 49,9\% więcej wnioskodawców niż wykazanych w okólniku. Według sprawozdań konsulatu z sierpnia i września 1925 r. podległy mu obszar opuściły 633 „rodziny”, tj. ok. 3 tys. osób. Pozwala to wysnuć wniosek, że na liście optantów nie znalazła się prawdopodobnie ok. 1/3 osób uczestniczących w zorganizowanej remigracji do Polski, która odbyła się w trzech turach w lipcu $1925 \mathrm{r}^{21}$ Tak czy inaczej zestawienia oparte na okólniku, odnoszące się zasadniczo do potencjalnych emigrantów z Zagłębia Ruhry, obejmują większą ogólną liczbę optantów (1727) niż te, które przygotował Pruski Krajowy Urząd Statystyczny w Berlinie dla całego państwa za cały 1925 r. (sic!). Instytucja ta odnotowała jedynie 1263 polskich optantów wraz członkami rodzin ${ }^{22}$, aczkolwiek należy zaznaczyć, że opracowująca wyniki Marie Philippi doskonale zdawała sobie sprawę z ich niedoskonałości, wynikającej z braku doświadczenia urzędu w gromadzeniu tego rodzaju danych, wdrażaniem nowego sposobu rejestracji - karty spisowe, a przede wszystkim większymi trudnościami w pozyskaniu informacji o osobach emigrujących niż imigrujących itp. ${ }^{23}$ Niemniej jednak opublikowano statystykę o emigracji z państwa pruskiego i imigracji doń; miała one bowiem ukazywać symptomy zjawiska ${ }^{24}$, szczególnie w odniesieniu do kategorii migrantów (obywatele/cudzoziemcy), struktury społeczno-zawodowej (weberowski podział) i kierunków migracji (kraje/rejencje). Potraktujmy zatem w ten sam sposób także dane z analizowanego źródła, zwłaszcza że uzyskany

${ }_{19}$ Ausführungsbestimmungen zum Artikel 91 des Vertrags von Versailles (Optionsordnung), Reichs-Gesetzblatt, nr 122 (8393), 3 XII 1921, § 1.

${ }^{20}$ Używanie określenia „rodzina” jest pewnym nadużyciem. Część osób składających wnioski opcyjne czyniła to bowiem indywidualnie.

${ }^{21}$ M. Piotrowski, Reemigracja..., s. 393-401.

${ }_{22}$ M. Philippi, Die Auswanderung und Einwanderung in Preußen im Jahre 1925, „Zeitschrift des Preußischen Statistischen Landesamts” 66, 1926, s. 380.

${ }^{23}$ Tamże, s. 378.

${ }^{24}$ Por. D. Szudra, Między obowiazkiem patriotycznym a koniecznościa ekonomiczna. Migracje w krainie „krwawiacej granicy” (Provinz Grenzmark Posen-Westpreussen). Uwagi źródłowe, w: Tempus nostrum est. Ksiega pamiatkowa ofiarowana profesorowi Edwardowi Włodarczykowi w 60. rocznice urodzin, red. D. Szudra, R. Techman, Szczecin 2006, s. 349. 
na ich podstawie obraz jest o wiele bardziej zbliżony do rzeczywistego, zarówno w wymiarze ogólnym, jak i strukturalnym.

Kto znalazł się na wykazach? Wydaje się, że w większości wnioskodawcy (i ich członkowie rodzin), którzy z trudem poddawali się procesowi akulturacji lub wiązali swą przyszłość $\mathrm{z}$ odrodzoną Polska, w związku z czym zamierzali wyjechać, korzystając zarazem z udogodnień wynikających ze statusu optanta, np. zwolnienia $z$ opłat celnych, nieponoszenia kosztów podróży i innych ${ }^{25}$. Nie bez znaczenia pozostaje tu fakt, że środowisko polonijne skupione $\mathrm{w}$ Bochum jeszcze przed wejściem w życie polskiego rozporządzenia „w przedmiocie nabycia i utraty obywatelstwa polskiego" z 13 VII 1920 r., które o prawie półtora roku wyprzedziło opublikowanie niemieckiego i którego ukazanie się było, mówiąc $\mathrm{w}$ dużym skrócie, związane $\mathrm{z}$ wkroczeniem $\mathrm{w}$ decydującą fazę wojny polsko-bolszewickiej, dając możliwość „wymuszenia” opcji na pozostałej w granicach państwa polskiego ludności niemieckiej na zasadzie: albo złożenie wniosku, albo wcielenie do wojska polskiego ${ }^{26}$ - otrzymało za pośrednictwem Stanisława Piechy zapewnienie od samego Naczelnika Państwa Józefa Piłsudskiego, że opcja na rzecz państwa polskiego nie będzie warunkiem sine qua non do późniejszego ubiegania się o obywatelstwo polskie ${ }^{27}$. Ponadto zalecenia powstrzymania się z decyzją o emigracji do Polski ze względu na trudną sytuację ekonomiczną w kraju płynęły do środowisk polonijnych Zagłębia Ruhry z Warszawy i Poznania (siedziba Ministerstwa byłej Dzielnicy Pruskiej) zanim ogłoszono powyższe rozporządzenie ${ }^{28}$, które zgodnie $\mathrm{z}$ literą traktatu wersalskiego wymagało złożenia oświadczenia opcji najpóźniej do 10 I 1922 r. Również Leon Barciszewski był orędownikiem powstrzymania emigracji, a kierowany przez niego konsulat w Essen opiniował selektywnie wnioski o nadanie obywatelstwa polskiego ${ }^{29}$. W związku z powyższym, by odwołać się do wartościującej opinii Jana Brejskiego, animatora życia polonijnego w Bochum, sprawującego w latach 1920-1924 urząd wojewody pomorskiego ${ }^{30}$ : „Najlepsi Polacy, nie optowali za Polską i zatrzymali uciążliwe piętno obywateli niemieckich" ${ }^{31}$.

\footnotetext{
${ }_{25}$ Por. M. Stażewski, Opcja..., s. 35.

${ }^{26}$ Tamże, s. 46 i in.; M. Stażewski, Przymusowy wyjazd..., s. 97.

${ }_{27}$ J. Brejski, Wspomnienia (z moich lat w Westfalii i Nadrenii) wraz z wprowadzeniem „Testament człowieka czynu narodowego i wspóttwórcy Kuźni Bochumsko-Westfalskiej”, oprac., red. i przyg. do dr. J. Papiór, Poznań 2018, s. 106.

28 Tamże, s. 104-105.

${ }^{29}$ W. Skóra, dz. cyt., s. 714-715.

${ }^{30} \mathrm{https}$ //www.porta-polonica.de/pl/lexikon/brejski-jan (27 XI 2019).

31 J. Brejski, dz. cyt., s. 106.
} 
W rekonstrukcji demograficznego obrazu optantów uzupełniające znaczenie maja pruskie leksykony gmin wydane dla Nadrenii ${ }^{32}$ i Westfalii ${ }^{33}$ na podstawie materiałów źródłowych ze spisu powszechnego z 1925 r. Zasadniczo posłużyły one do przypisania miejsca zamieszkania optantów do najmniejszych jednostek podziału administracyjnego, tj. gmin miejskich i wiejskich, następnie powiatów miejskich i wiejskich, rejencji i wreszcie największych - prowincji. Wprawdzie informacje z obu wydawnictw nie odnoszą się do podziału terytorialnego z czerwca 1925 r., gdyż liczbę ludności podano w nich według administracyjnych granic gmin z grudnia 1930 czy marca 1931 r., to jednak z powodu znacznych zmian mających miejsce w Zagłębiu Ruhry po 1905 r. ${ }^{34}$ (rok, dla którego ukazały się ostatnie przedwojenne leksykony) bardziej zasadne staje się dopasowanie podziału terytorialnego do tego, który istniał kilka lat po 1925 r., mając na uwadze, że w krótszym okresie - odznaczającym się również spowolnieniem dynamiki przyrostu liczby ludności - gros gmin zapewne nie zmieniło swej powierzchni administracyjnej lub nie uległo likwidacji, podziałowi czy scaleniu. Należy również zwrócić uwagę na fakt, że w adresach optantów w niektórych wypadkach brakowało miejscowości tożsamej z nazwa gminy, podano bowiem tylko dzielnice miast (Stadtteile) czy nawet miejsca zamieszkania (Wohnplätze), które na szczęście są możliwe do zlokalizowania dzięki leksykonom i mapie Europy Środkowo-Wschodniej ${ }^{35}$. W trakcie lokalizowania i geokodowania przypisano współrzędne geograficzne wszystkim 83 miejscowościom, natomiast do prezentacji danych na mapach tematycznych - z użyciem metody kartodiagramu punktowego skokowego prostego i strukturalnego - zastosowano agregację danych na poziomie gmin miejskich i wiejskich w liczbie 39, aby lepiej uwidocznić panujące tendencje.

Owego przechodzenia od szczegółu do ogółu dokonano także w grupowaniu statystycznym, którego zasadniczą formę wypracowano

${ }^{32}$ Gemeindelexikon für den Staat Preussen, t. 13: Provinz Rheinprovinz. Nach dem endgültigen Ergebnis der Volkszählung vom 16. Juni 1925 und anderen amtlichen Quellen unter Zugrundelegung des Gebietsstandes vom 1. Dezember 1930, oprac. Preußischen Statistischen Landesamt, Berlin 1930, s. 1-202.

${ }^{33}$ Gemeindelexikon für den Staat Preussen, t. 11: Provinz Westfalen. Nach dem endgültigen Ergebnis der Volkszählung vom 16. Juni 1925 und anderen amtlichen Quellen unter Zugrundelegung des Gebietsstandes vom 1. März 1931, oprac. Preußischen Statistischen Landesamt, Berlin 1931, s. 1-109.

${ }^{34}$ Zob. H. Matzerath, Urbanisierung in Preußen 1815-1914, Stuttgart 1985, s. 249-250 i in.; J. Reulecke, Geschichte der Urbanisierung in Deutschland, Frankfurt am Main 1985, s. 84-86.

${ }_{35}$ Zob. m.in. Übersichtskarte von Mitteleuropa, oprac. Reichsamt für Landesaufnahme, Berlin 1940 (Sonderausgabe vom 10.3.1940, J 54 K 52, Maßstab: 1:300 000). 
i przedstawiono w artykułach poświęconych polskim optantom z rejencji pilskiej, stralsundzkiej i szczecińskiej, uzupełniając tabelę poświęcona zawodom o międzynarodowe klasyfikacje HISCO ${ }^{36}$ i HISCLASS ${ }^{37}$. Daje to również możliwość przeprowadzenia pierwszych porównań. Zainteresowany czytelnik znajdzie we wspomnianych już publikacjach uwagi metodyczne $^{38}$. Warto w tym miejscu nadmienić, że wykazane w okólniku osoby, które złożyły oświadczenie opcji, zróżnicowałem m.in. poprzez określenie typu ich gospodarstwa domowego (rodzinnego) z wykorzystaniem zmodyfikowanej przez Cezarego Kuklę ${ }^{39}$ typologii Petera Lasletta ${ }^{40}$, pamiętając jednocześnie o niedogodnościach wynikających z rozróżnienia na niepełnoletnie (niesamodzielnie optujące) i pełnoletnie dzieci (samodzielnie optujące). Związany z tym problem klasyfikacyjny próbowałem w pewnej mierze obejść poprzez rekonstrukcję rodzin możliwą do przeprowadzenia na podstawie danych adresowych. Dysponując informacjami z okólnika i leksykonów, na potrzeby niniejszej pracy zaprojektowałem i utworzyłem bazę danych składającą się z trzech tabel: gminy, wnioskodawcy, członkowie - połączonych relacją jeden do wielu, w której klucz podstawowy gminy jest kluczem obcym wnioskodawcy, a klucz podstawowy wnioskodawcy pełni funkcję klucza obcego dla członka rodziny. Pozwoliło to efektywniej zarządzać danymi i wykonywać niezbędne SQL-owe kwerendy. Oprócz metody agregacyjnej zastosowałem kilka procedur obliczeniowych z bogatego zasobu ekonometrii, sięgnąwszy po popularną miarę koncentracji Corrado Giniego ${ }^{41}$ czy sposób podziału zbioru Zdzisława Hellwiga ${ }^{42}$. Podstawę do wyciagania wniosków stanowi jednak „tradycyjna” ocena tendencji centralnej czy częstości występowania danych kategorii (zob. aneks).

${ }^{36}$ Więcej na ten temat: https://iisg.amsterdam/en/data/data-websites/history-of-work (20 IX 2020).

${ }^{37}$ M.H.D. van Leeuwen, I. Mass, HISCLASS. A Historical International Social Class Scheme, Leuven 2011.

${ }^{38}$ Zob. przyp. 11.

${ }^{39}$ C. Kuklo, Demografia Rzeczypospolitej przedrozbiorowej, Warszawa 2009, s. 153.

${ }^{40} \mathrm{Na}$ temat złożoności zagadnienia i potrzeb badawczych w kontekście historycznej analizy gospodarstw domowych zob. M. Szołtysek, Toward a Conceptual Framework for the Variation in Historical Family and Household Systems Across Eurasia, „Przeszłość Demograficzna Polski” 36, 2014, s. 55-86.

${ }^{41} \mathrm{P}$. Sudra, Zastosowanie wskaźników koncentracji przestrzennej w badaniu procesów urban sprawl, „Przegląd Geograficzny” 88, 2016, nr 2, s. 252.

42 J. Runge, Metody badań $w$ geografii społeczno-ekonomicznej-elementy metodologii, wybrane narzędzia badawcze, Katowice 2007, s. 235-237. 


\section{Wyniki i dyskusja}

Nie ulega wątpliwości, że liczba polskich optantów wykazanych w okólniku (1727 osób), o których możemy mówić jako o potencjalnych emigrantach, była kilkunastokrotnie mniejsza ${ }^{43}$ od grupy Polonii zamieszkującej obszar znajdujący się w kompetencji konsulatu w Essen, i to mimo uszczuplenia potencjału tej ostatniej wskutek powojennej emigracji do Francji, Belgii czy Holandii oraz reemigracji do Polski, głównie do Wielkopolski, gdzie według sprawozdań starostów z lat 1919-1923 miało powrócić z Niemiec 55 tys. Polaków, z czego 3/4 w pierwszych dwóch powojennych latach ${ }^{44}$. Rozkład przestrzenny liczby optantów właściwie korespondował z tym, który ukształtował się $\mathrm{w}$ procesie historycznym w odniesieniu do ludności polskojęzycznej, innymi słowy był jego pochodna (szkicowo na temat tendencji Krystyna Murzynowska) ${ }^{45}$. Zdecydowana większość wnioskodawców i członków ich rodzin zamieszkiwała po obu stronach rzeki Emschery na obszarach wchodzących w skład pruskich prowincji Westfalia (w rejencjach Arnsberg - 31\% i Münster - 26,4\%) i Nadrenia (w rejencji Düsseldorf - 43,5\%), z reguły nie dalej niż do rzek Lippe na północy i Ruhry na południu, przy czym większe skupiska interesujących na osób występowały w pasie Dortmund-Duisburg-Hamborn, nie przekraczając lewego brzeg Renu (zob. mapy $1-2$, tab. 1-2).

Jak widać, optanci zamieszkiwali głównie obszar Zagłębia Ruhry, którego rozwój gospodarczy był siłą przyciagająca szczególnie niewykwalifikowaną ludność, znajdująca zatrudnienie w nowo zakładanych kopalniach węgla kamiennego, hutnictwie i innych branżach przemysłu ciężkiego. Z pracy w nim utrzymywało się ponad $80 \%$ mieszkających tam Polaków ${ }^{46}$. Podobnie rzecz się miała z polskimi optantami (zob. mapa 3, tab. 4). W większości podstawowych jednostek administracyjnych przeważali ci, których źródłem utrzymania była praca w górnictwie i hutnictwie, przy czym można dostrzec, że osoby zatrudnione w tej drugiej branży zamieszkiwały głównie miejscowości położone na południe od rzeki Emschery, wykazując największe skupienie w gminie Duisburg-Hamborn (powiat miejski). Nie powinno to zresztą dziwić z uwagi

${ }^{43}$ Zob. wyniki statystyki językowej z 1925 r. opracowane dla wybranych 11 powiatów w Zagłębiu Ruhry: K. Keller, dz. cyt., s. 184 (tab. 19: Die Muttersprache im Ruhrgebiet).

${ }^{44}$ M. Nadobnik, Wyludnianie się wsi Wielkopolskiej, „Ruch Prawniczy, Ekonomiczny i Socjologiczny" 17, 1937, nr 1, s. 100*.

${ }_{45}$ Zob. K. Murzynowska, Polskie wychodźstwo zarobkowe w Zagtębiu Ruhry w latach 1880-1914, Wrocław 1972, s. 29.

${ }^{46}$ Por. K. Keller, dz. cyt., s. 182. 


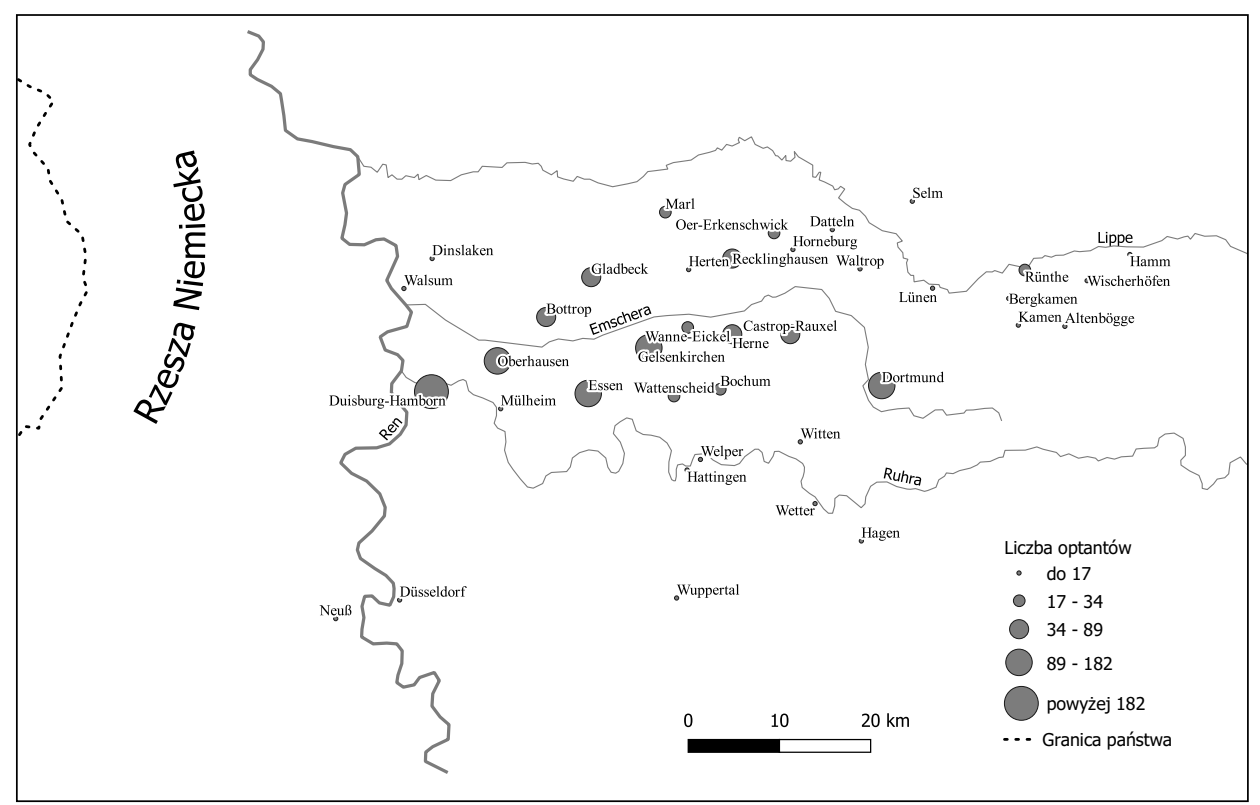

Mapa 1. Liczba polskich optantów w okręgu konsularnym Essen w grudniu 1924 r. według rozmieszczenia $\mathrm{w}$ gminach

Źródło: oprac. własne na podstawie źródeł wymienionych w tab. 1.

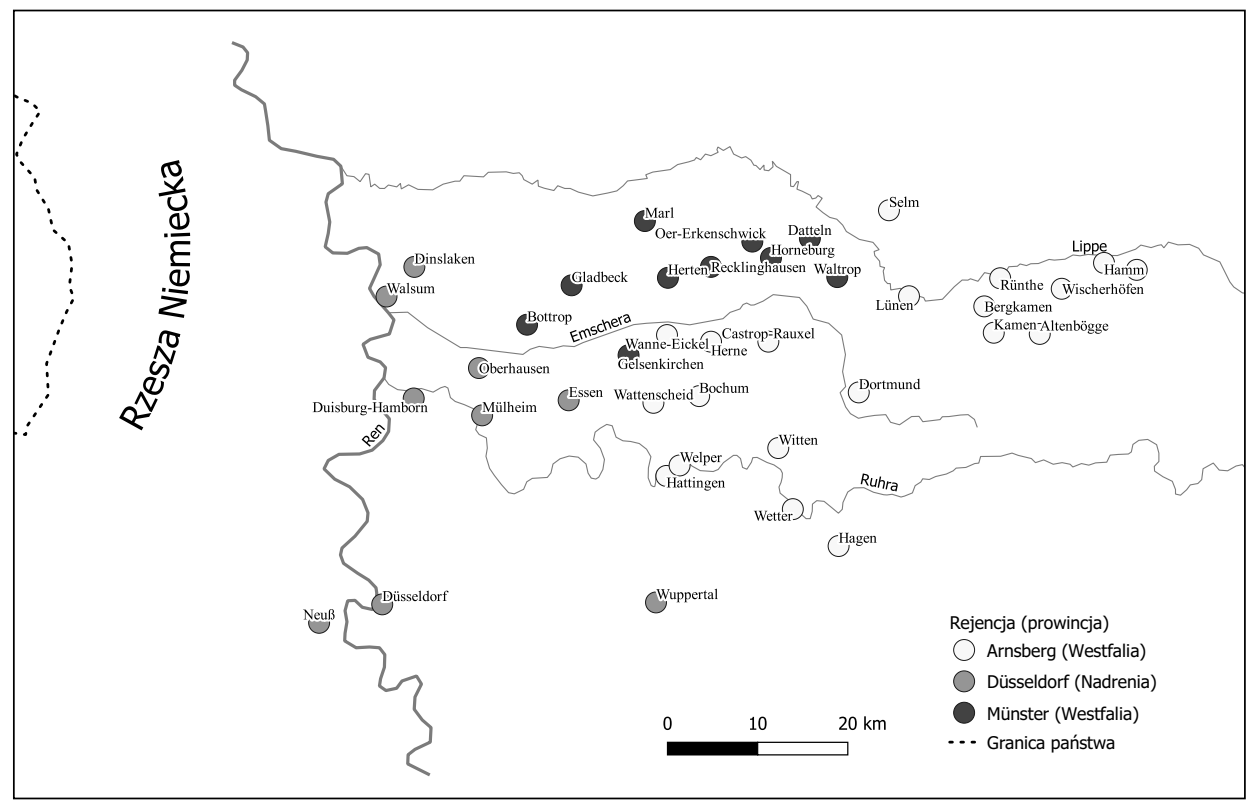

Mapa 2. Gminy z polskimi optantami w okręgu konsularnym Essen w grudniu 1924 r. według przynależności do rejencji

Źródło: oprac. własne na podstawie źródeł wymienionych w tab. 1. 


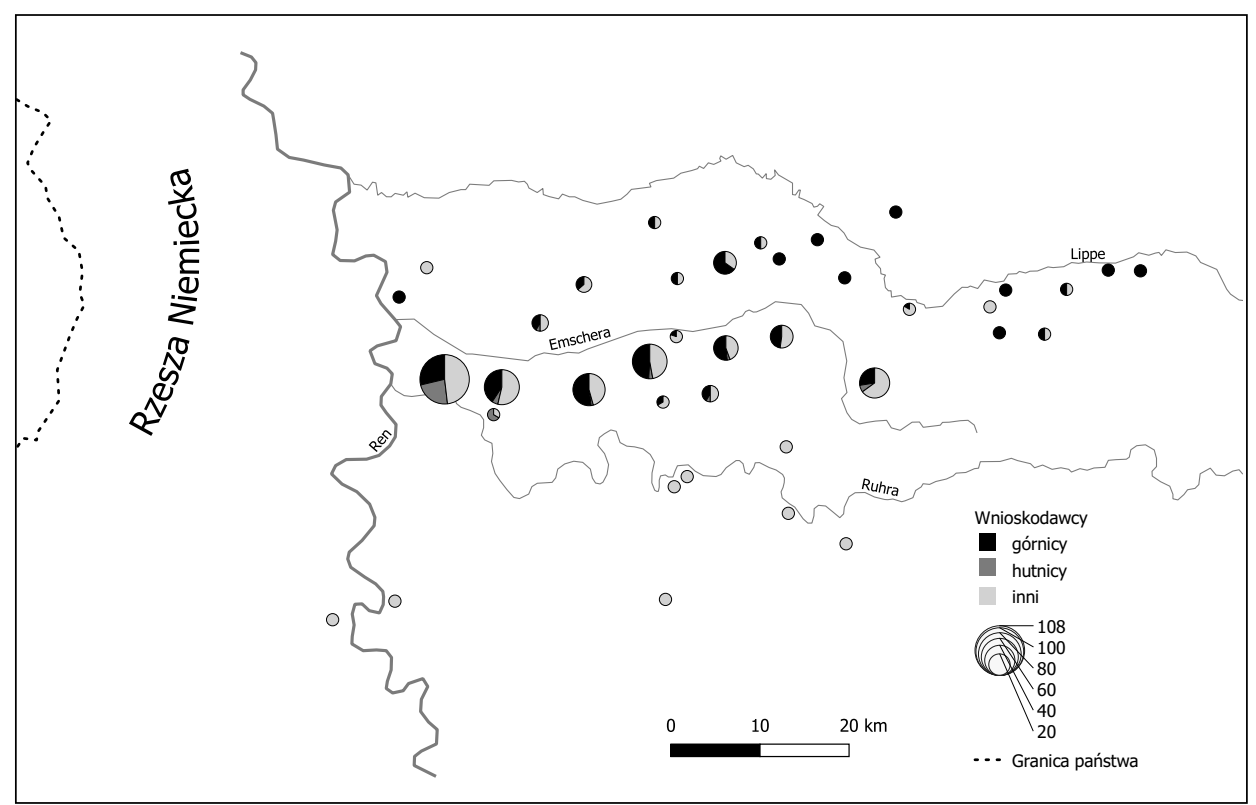

Mapa 3. Liczba polskich optantów w okręgu konsularnym Essen w grudniu 1924 r. według rozmieszczenia w gminach i wykonywanych zawodów

Źródło: oprac. własne na podstawie źródeł wymienionych w tab. 1.

na fakt, że Duisburg - mający dogodne warunki transportowe, m.in. największy śródlądowy port Europy - stanowił główny ośrodek hutnictwa żelaza w Niemczech. Z tego nadreńskiego miasta doków, węgla i stali, z przyłączonym doń Hamborn, rekrutowało się najwięcej polskich optantów. Ich liczba, która wyniosła 108 wnioskodawców i 386 osób objętych opcja, biorac pod uwage mocne kryterium podziału zbioru Hellwiga, odstawała znaczaco od zanotowanej dla pozostałych jednostek administracyjnych. Zastosowawszy umiarkowane kryterium podziału, można wydzielić kolejna grupę gmin, w których liczba wnioskodawców odbiegała wyraźnie od innych i tworzyła osobny zbiór, a mianowicie Oberhausen $(54 ; 182)$, Gelsenkirchen $(53 ; 171)$, Essen $(46 ; 155)$ i Dortmund $(40 ; 131)$. Na terenie wymienionych pięciu jednostek administracyjnych zamieszkiwało łącznie $62,3 \%$ wszystkich optantów z obszaru podległego konsulatowi w Essen. Co ciekawe, do grupy czterech wiceliderów „W opcji” nie zaliczało się miasto Bochum $(11 ; 55)$, ośrodek życia polonijnego, co może mieć związek ze skutecznością prowadzonej tam akcji pod hasłem ${ }^{47}$ : pozostańcie na miejscu!

${ }^{47}$ J. Brejski, dz. cyt., s. 104. 
Wprawdzie najwięcej optantów zamieszkiwało duże gminy liczące 50 tys. i więcej mieszkańców $(89,2 \%$ wnioskodawców, $88,3 \%$ wszystkich objętych opcja), to jednak należy mieć na uwadze, że socjologiczna wymowa powyższego faktu traci na znaczeniu w przypadku konurbacji charakteryzującej się ciagłością tkanki miejskiej ${ }^{48}$. Ponadto w gęsto zaludnionym środowisku optanci stanowili zaledwie 4\%o ogółu populacji gmin, w których zamieszkiwali, co pokazuje pewna „znikomość” analizowanego przedmiotu badań pod względem ilościowym (zob. tab. 4), a analiza struktury zawodowej utwierdza w przekonaniu, że raczej wśród wnioskodawców wymienionych w okólniku nie znalazły się jednostki zamożne, wykształcone czy parające się wolnymi zawodami. Gros wnioskodawców lokowało się w dolnych grupach społecznych, mianowicie w dziewiątej i wyższej biorąc pod uwagę klasyfikację HISCLASS (pracownicy o niższych kwalifikacjach zawodowych lub niewykwalifikowani) ${ }^{49}$. Łącznie $\mathrm{z}$ niepodającymi lub nieposiadającymi zawodu stanowili oni aż 86\% wśród osób składajacych opcję; innymi słowy owa późna reemigracja do kraju nosiła przede wszystkim znamiona robotniczo-rzemieślniczej, z bardzo silnym położeniem akcentu na pierwszy człon. Wiedli w niej prym górnicy (41,3\%), co również - aż nadto - znajduje swoje potwierdzenie w owych symptomatycznych liczbach dla całych Prus $(39,4 \%)^{50}$. Daje to asumpt do wysunięcia przypuszczenia, że władze niemieckie miały najlepsze rozeznanie w ruchu optantów właśnie w odniesieniu do Zagłębia Ruhry. Dominację wspomnianej kategorii zawodowej obrazuje wymiernie wysoka wartość współczynnika Giniego, która dla liczebności 35 określeń zawodów w skali od 0 do 1 wyniosła aż 0,798 (bez kategorii „brak danych” - 0,805). Z badań przeprowadzonych dla rejencji pilskiej, stralsundzkiej i szczecińskiej ${ }^{51}$ oraz zestawień zaprezentowanych przez Mirosława Piotrowskiego dla innych okręgów: Hamburg, Kwidzyn i Berlin ${ }^{52}$ - wynika niezbicie, że reprezentanci średnich i wyższych klas społecznych, pamiętając o ich szczupłości

${ }^{48}$ Zob. B. Hamm, Wprowadzenie do socjologii osadnictwa, tłum. A. Rosłan, Warszawa 1990, s. $30 \mathrm{i}$ in.

49 Zob. M.H.D. van Leeuwen, I. Mass, dz. cyt., s. 57 (grupy HISCLASS), s. 131-181 (konkordancja z HISCO). Podana klasyfikacja w tab. 4 być może nie do końca odzwierciedla stan faktyczny lokowania się w danej grupie społecznej, zważywszy na brak dodatkowych informacji o pozycji w wykonywanym zawodzie, np. atrybutu „mistrz”. Niemniej jednak wydaje się, że dobrze oddaje tendencję strukturalną rozpatrywanego zjawiska.

${ }^{50}$ M. Philippi, dz. cyt., s. 390-391.

${ }^{51}$ D. Szudra i in., dz. cyt., s. 30-31; D. Szudra, Optanci polscy w rejencji stralsundzkiej..., s. 55; D.K. Chojecki, Optanci polscy..., s. 99.

${ }^{52}$ M. Piotrowski, Reemigracja..., s. 364-368, 372-373, 378-382. 
liczebnej na analizowanym obszarze ${ }^{53}$, właściwie nie uczestniczyli w interesujących nas ruchach migracyjnych, co z kolei prowadzi do dwóch niewykluczających się wzajemnie przypuszczeń: że brali oni udział w ruchach powrotnych tuż po zakończeniu wojny, uczestnicząc w początkowym etapie odbudowy czy przejmowania struktur państwowych, samorządowych i komunalnych w odrodzonej Polsce (tzw. krąg westfalczyków) ${ }^{54}$, lub nie brali w nich udziału z uwagi na swoje większe możliwości adaptacyjne w niemieckim środowisku.

Zjawisko przewagi liczebnej kobiet nad mężczyznami, z powodu tzw. nadumieralności mężczyzn ${ }^{55}$, ma charakter powszechny w populacjach, w których selektywnie działający czynnik migracyjny i kulturowy nie odgrywa roli. Z reguły w migracjach długodystansowych i długookresowych uczestniczą częściej mężczyźni niż kobiety ${ }^{56}$. Znajduje to również potwierdzenie w danych odnoszących się do polskojęzycznej ludności w Zagłębiu Ruhry, wystarczy wspomnieć, że w 1890 r. udział kobiet $\mathrm{w}$ tej grupie ludności wynosił zaledwie 39,5\%, by w 1910 r. zanotować już poziom $76,7 \%{ }^{57}$. Forpocztę w procesach osadniczych stanowili zatem głównie mężczyźni, którzy po osiedleniu się, zwykle przy nowo powstałej kopalni, zakładali rodziny, najczęściej wchodząc, o ile nie byli już żonaci, w związki małżeńskie z Polkami przybyłymi z ziem zaboru pruskiego

${ }^{53}$ O. Steinert, Tygiel vs. subkultura. Integracja polskich migrantów $w$ Berlinie i w Zagtębiu Ruhry (1871-1918), w: Schimanski, Kuzorra i inni..., s. 70-71.

${ }^{54} \mathrm{Na}$ przykład gros działaczy największej polskiej organizacji w Zagłębiu Ruhry, tj. Zjednoczenia Zawodowego Polskiego, przeniosło się do Polski, by tu rozwijać i prowadzić akcję organizacyjna; por. J. Kozłowski, Zjednoczenie Zawodowe Polskie i jego działalność w Zagtębiu Ruhry 1902-1939, w: tamże, s. 157.

55 Zob. A. Fihel, Pteć a trwanie życia. Analiza demograficzna, Warszawa 2012 , s. $15-22$.

${ }^{56}$ Zob. W. Feld, Zur Geschlechtsgliederung der städtischen und ländlichen Bevölkerung, „Allgemeines Statistisches Archiv” 17, 1907, pierwszy półrocznik, s. 212-213 (maskulinizacja w państwie Prusy w podziale na miejsce urodzenia: gmina spisowa/ poza gmina spisowa, i wielkość gminy: 20 tys. i mniej/20 tys. i więcej osób, w latach spisowych 1871, 1880, 1890, 1900). Wniosek o dominacji mężczyzn we wspomnianych migracjach stoi w pewnej opozycji do sławnego stwierdzenia E.G. Ravensteina, rozpoczynającego fragment poświęcony migracji kobiet: „Woman is a greater migrant than man. This may surprise those who associate women with domestic life, but the figures of the census clearly prove it. Nor do women migrate merely from the rural districts into the towns in search of domestic service, for they migrate quite as frequently into certain manufacturing districts, and the workshop is a formidable rival of the kitchen and scullery”; tenże, The Laws of Migration, „Journal of the Statistical Society of London” 1885, 48, nr 2, s. 196. Ustalenia poczynione dla Anglii i Walii niekoniecznie można odnieść do sposobu migrowania ludności polskiej do Zagłębia Ruhry, w czym istotną rolę odgrywały czynniki kulturowe i specyfika zatrudnienia w przemyśle ciężkim.

${ }^{57}$ K. Murzynowska, dz. cyt., s. 26 (tab. 10). 
czy Mazur lub Górnego Śląska (forma specyficznej małżeńskiej migracji łańcuchowej). Pierwsi osadnicy torowali drogę następnym, którzy przy sprzyjających warunkach również zakładali rodziny (lub wędrowali z rodzinami). Można zakładać, że przy stale rozwijajacej się sieci kontaktów kobiety z wolna zyskiwały coraz większy udział w grupie indywidualnie migrujacych osób ${ }^{58}$. W miarę upływu czasu prowadziło to do obniżania się poziomu maskulinizacji ludności napływowej, w czym też istotną rolę odgrywała mniej selektywnie oddziałująca reprodukcja, jednakże ciagły napływ kolejnych migrantów powodował utrzymywanie się - wprawdzie malejącej - liczebnej przewagi mężczyzn nad kobietami. Jak można zasadnie przypuszczać, ten sam mechanizm był przyczyną tego, że w wśród optantów z obszaru kompetencyjnego konsulatu w Essen na 100 mężczyzn przypadało 90-91 kobiet (zob. tab. 5). Szczególnie wyraźnie zjawisko maskulinizacji było widoczne w grupie indywidualnych wnioskodawców, czyli tych, którzy nie byli w związku małżeńskim ani nie mieli dzieci, na które rozciagałoby się prawo opcji. Wśród 156 optantów spełniających to kryterium wskaźnik feminizacji wyniósł zaledwie 52,9. Innymi słowy, przeciętnie na jedną kobietę przypadało tu prawie dwóch mężczyzn, co pośrednio utwierdza w przekonaniu, że wśród osób indywidualnie migrujących do Zagłębia Ruhry przeważali mężczyźni (później podejmujący też decyzję o reemigracji) lub że byli oni skłonni częściej podjąć ryzyko powrotu. Dodajmy, że przewaga ta stałaby się jeszcze większa wraz z wyłączeniem z powyższej grupy wnioskodawców innych osób - przede wszystkim pełnoletnich dzieci zamieszkujacych wspólnie z rodzicami. Z podobnym zjawiskiem mamy również do czynienia w przypadku indywidualnie składajacych opcję w rejencji pilskiej czy szczecińskiej ${ }^{59}$, ale wśród nich wskaźniki feminizacji nie kształtowały się aż tak wyjątkowo na korzyść mężczyzn jak w Zagłębiu Ruhry, a w przypadku rejencji stralsundzkiej ${ }^{60}$ ujawniło się nawet znaczące sfeminizowanie tej grupy - na 10 mężczyzn przypadało przeciętnie aż 15 kobiet, co zapewne wynikało tam ze specyfiki funkcjonowania wielkich majątków ziemskich, które w skali całych Niemiec dominowały ekstremalnie na obszarze Neu Vorpommern i zgłaszały zapotrzebowanie na żeńskie siły robocze.

Rzuca się też w oczy fakt, że w okręgu konsularnym Essen udział „indywidualnych" wnioskodawców w ogólnej liczbie osób objętych opcją (9\%)

${ }^{58}$ Wprowadzenie do fenomenu migracji łańcuchowych zob. D. Praszałowicz, K.A. Makowski, A.A. Zięba, Mechanizmy zamorskich migracji łańcuchowych w XIX wieku: Polacy, Niemcy, Żydzi, Rusini. Zarys problemu, Kraków 2004, s. 29-37.

59 D. Szudra i in., dz. cyt., s. 29; D.K. Chojecki, Optanci polscy..., s. 98.

${ }^{60}$ D. Szudra, Optanci polscy $w$ rejencji stralsundzkiej..., s. 54. 
był około dwukrotnie mniejszy od tego, którym odznaczały się trzy porównywane rejencje (16,8-19,3\%). Czyżby zatem polscy optanci z zachodniej, najbardziej uprzemysłowionej części Niemiec tworzyli potencjalnie trzon w największym stopniu rodzinnej emigracji? Nie ulega wątpliwości, że przekrojowa zastana „dzietność” w rodzinach - dodajmy, że siłą rzeczy także nieujmująca dzieci zmarłych przed sporządzeniem wykazu ${ }^{61}-$ należała tu do najwyższych (zob. tab. 7). Na jedno małżeństwo lub rodzica przypadało bowiem przeciętnie co najmniej 2,89 dziecka (325 rodzin; 939 dzieci), podczas gdy na obszarze Pogranicza, również cechującego się wysoką płodnością w skali całych Niemiec ${ }^{62}$, optanci nie odznaczali się już tak wysokim wynikiem przeciętnej: 2,81 (375 rodzin; 1054 dzieci) ${ }^{63}$, wskaźnik ten zaś był jeszcze niższy dla środkowej ${ }^{64}$ i zachodniej części ${ }^{65}$ prowincji Pomorze, kształtując się na poziomie 2,66 i 2,05, co może też sugerować, że przebywający tam optanci byli po prostu mniej zasiedziali, bardziej wyobcowani i funkcjonowali w o wiele rzadszej sieci powiązań towarzyskich. Wysoka dzietność w Zagłębiu Ruhry była w największym stopniu kształtowana przez zachowania prokreacyjne ludności górniczej, czego dowodzą też badania w makroskali przeprowadzone przez Patricka R. Gallowaya i innych ${ }^{66}$, a przede wszystkim wyniki spisowe ${ }^{67}$. W grupie polskich optantów utrzymujących się z pracy w kopalni wyniosła ona aż 3,20 (155 rodzin; 496 dzieci) i przewyższała znacznie wyliczona dla robotników i hutników. W rodzinach górników najczęściej było 3 lub 4 dzieci, podczas gdy w robotniczych - tylko jedno (co też mogło być po części uwarunkowane różnicami związanymi z czasem zasiedlenia i zatrudnienia - najpierw zapewne głównym magnesem przyciagajacym był rozwój górnictwa, następnie innych gałęzi przemysłu ciężkiego).

61 Wprowadzenie do zagadnień związanych z umieralnością $\mathrm{w}$ regionie daje: M. Weyer-von Schoultz, Stadt und Gesundheit im Ruhrgebiet 1850-1929. Verstädterung und kommunale Gesundheitspolitik am Beispiel der jungen Industriestadt Gelsenkirchen, Essen 1994, s. 133-152.

${ }^{62}$ Beiträge zum deutschen Bevölkerungsproblem. Der Geburtenrückgang im Deutschen Reich. Die allgemeine deutsche Sterbetafel für die Jahre 1924-1926, Berlin 1929 (Sonderhefte zu „Wirtschaft und Statistik”, 5), s. 13-15, 31.

${ }^{63}$ D. Szudra i in., dz. cyt., s. 33.

${ }^{64}$ D.K. Chojecki, Optanci polscy..., s. 100.

${ }^{65}$ D. Szudra, Optanci polscy $w$ rejencji stralsundzkiej..., s. 55.

${ }^{66}$ P.R. Galloway, E.A. Hammel, R.D. Lees, Fertility Decline in Prussia, 1875-1910. A Pooled Cross-Section Time Series Analysis, „Population Studies” 48, 1994, s. 156-158.

${ }^{67}$ „Wirtschaft und Statistik” 23, 1943, nr 5 (Beruf und Kinderzahl in Stadt und Land. Weitere familienstatistische Ergebnisse der Volkszählung 1939), s. 120, 129 (Tabelle 2: Die Durschnittliche Kinderzahl der Ehepaare auf dem Lande und in den Großstädten nach dem Beruf des Ehemannes und nach Bodenwirtschaftung). 
Mało tego, w interesującej nas grupie zawodowej średnia liczba dzieci przypadająca na rodzinę była wyższa od tej, którą charakteryzowali się polscy rolnicy optanci w Marchii Granicznej Poznańskie-Prusy Zachodnie $-3,12$ (120 rodzin; 387 dzieci) ${ }^{68}$. O ile wysoką zastana dzietność wśród osób utrzymujących się ówcześnie z pracy na roli można łatwo wytłumaczyć, a mianowicie potrzebą zapewnienia dodatkowych rak do pracy w gospodarstwie i obniżeniem tym samym kosztów jego funkcjonowania, o tyle sprawia to pewną trudność w odniesieniu do pracujacych w ciemności, duchocie, pyle i stałym zagrożeniu życia, ale w miare dobrze opłacanych górników, wykazujących się znaczną solidarnościa grupowa. W niemieckiej literaturze demograficznej, jak się wydaje, właściwie tylko Paul Mombert próbował wyjaśnić ten fenomen, nawiąując do poglądów Herberta Spencera i pewnego dialogu z Kubusia Fatalisty Diderota $^{69}$. Otóż specyficzny rodzaj pracy pod ziemią zdaniem Momberta miał się przyczyniać do tego, że u górników kosztem innych przyjemności życia na pierwszy plan, i to zdecydowanie, wysuwało się zaspakajanie potrzeb seksualnych, by - dopowiedzmy - „odreagować” stres wynikający z długotrwałego stanu zagrożenia i „złagodzić” zmęczenie fizyczne, które często odsuwało na bok potrzebę korzystania z innych, bardziej wysublimowanych przyjemności życia. Wysoka dzietność w rodzinach górniczych miała też znajdować swoje czysto biologiczne uzasadnienie w fakcie, że większa zdolność do reprodukcji występuje u przedstawicieli gatunków bardziej narażonych na przedwczesną utratę życia (strategia rozwoju ilościowego) ${ }^{70}$. Warto nadmienić, że Patrick R. Galloway, Ronald D. Lee i Eugene A. Hammel pod koniec XX w. wysunęli ostrożnie hipotezę, w świetle której interesujące nas zjawisko w Zagłębiu Ruhry mogło być uwarunkowane czynnikiem ekonomicznym, a mianowicie tym, że dzieci górników częściej podejmowały pracę, wspierając tym samym finansowo budżet domowy ${ }^{71}$. Jest to jednak wyjaśnienie niesatysfakcjonujace, myli bowiem raczej przyczynę ze skutkiem.

Odsuwając na bok aspekty związane z symptomatycznymi rozmiarami dzietności, populację omawianej grupy optantów można również

${ }^{68}$ D. Szudra i in., dz. cyt., s. 33.

${ }^{69}$ P. Mombert, Studien zur Bevölkerungsbewegung in Deutschland in den letzten Jahrzehnten mit besonderer Berücksichtigung der ehelichen Fruchtbarkeit, Karlsruhe 1907 , s. 164, 243-244.

${ }^{70} \mathrm{Z}$ różnych perspektyw ciekawie o związkach seksu i śmieci w kontekście biologicznym i antropologicznym traktuje książka: J. Ruffié, Seks i śmierć, tłum. B.A. Matusiak, Warszawa 1997.

${ }^{71}$ P.R. Galloway, E.A. Hammel, R.D. Lee, Urban versus Rural: Fertility Decline in the Cities and Rural Districts of Prussia, 1875 to 1910, „European Journal of Population” 14, 1998, s. 225. 
rozpatrywać pod względem struktury ich gospodarstw domowych, zarówno indywidualnych, jak i rodzinnych, pamiętając przy tym, że typy form współzamieszkiwania są w analizowanym przypadku „skażone” charakterem kontrolno-sprawozdawczym źródła (zob. tab. 6a i 6b). I tak jedność rodzin zamieszkujących wspólnie jest niekiedy sztucznie rozbita poprzez wydzielenie w wykazach pełnoletnich dzieci. Podstawowy problem z tymi ostatnimi polega na tym, że ich relacja względem głowy rodziny nie jest w żaden sposób sygnalizowana. Przy próbie jej ustalenia skazani jesteśmy na domysły na podstawie danych o imieniu, nazwisku, posiadanym zawodzie i adresie zamieszkania. Ponadto, aczkolwiek zapewne o wiele rzadziej, indywidualnie składający oświadczenie o opcji mogli być członkami rodzin w linii bocznej lub wstępnymi - np. któryś z dziadków - zamieszkującymi to samo trójpokoleniowe rodzinne gospodarstwo domowe. Oczywiście jest więcej możliwych konfiguracji komplikujacych spojrzenie na funkcjonowanie rodzinnego gospodarstwa domowego, by nie wspomnieć też o patriarchalnej nadrzędności decyzji męża względem żony będącej w ówczesnych realiach bierną optantka, bo pozbawioną możliwości decydowania o swoim losie mimo posiadanej pełnoletności (problem statusu) ${ }^{72}$, czy o współzamieszkiwaniu niespokrewnionych bądź niespowinowaconych osób z głową rodzinnego gospodarstwa domowego (problem tzw. przychodzacych spać na noc - zjawisko Schlafgängerei; kostników itd. ${ }^{73}$ ).

Tych kilka powyższych uwag powinno pozwolić lepiej zrozumieć, dlaczego zastosowanie typologii Petera Lasletta w odniesieniu do interesującego nas wykazu może na pierwszy rzut oka stwarzać wrażenie, że gospodarstwa jednoosobowe optantów miały tak duże znaczenie w analizowanej grupie (1_c - 31,9\%) $)^{74}$, co z kolei rzutowało na pomniejszenie udziału ich rodzinnych gospodarstw o nuklearnym charakterze, czyli składających się z samego małżeństwa, małżeństwa lub rodzica z dzieckiem bądź dziećmi, w grupie których, siłą rzeczy, na pierwszy plan wysuwały się te utworzone $\mathrm{z}$ tzw. pełnych rodzin $\left(3 \_b-53,6 \%\right)$. A jednak i przez pryzmat tych danych można dostrzec wysoce rodzinny charakter optantów z Zagłębia Ruhry. Ukazuje go relacja typu 3 (rodziny nuklearne) do typu $1_{-}$(osoby z reguły samotnie prowadzące

72 Zob. przepisy dotyczące podporządkowania się żony woli męża: Niemiecki kodeks cywilny wraz z ustawq wprowadcza, tłun. H. Damm, K. Gerschel, cz. 2, Bydgoszcz 1922 (ks. IV: Prawo familijne, rozdz. I: Małżeństwo, § 1354 i 1356).

${ }^{73}$ K. Murzynowska, dz. cyt., s. 61-63.

${ }^{74}$ Ponieważ w ogóle nie podawano stanu cywilnego „panna” i „kawaler” można przyjąć, że zdecydowana większość osób, o ile nie wszystkie, zakwalifikowanych do typu 1_c przynależała de facto do typu 1_a. 
gospodarstwo domowe). Na obszarze leżącym w kompetencji konsulatu w Essen na dwie rodziny przypadał tylko jeden indywidualny wnioskodawca, czyli taki - powtórzmy - którego decyzja o opcji nie rozciagała się na małżonkę lub niepełnoletniego bądź niepełnoletnich członków rodziny. Natomiast na rolniczym obszarze Marchii Granicznej Poznańskie-Prusy Zachodnie stosunek ten był równy jedności (sic!) ${ }^{75}$. Tak diametralną różnicę można próbować wyjaśnić następująco: w przeciwieństwie do napływowej ludności w Zagłębiu Ruhry, polska społeczność Pogranicza trwała od wieków na swojej ziemi, przy czym z powodu powolnego rozwoju gospodarczego obszaru „peryferyjnego”"76, za jaki uchodziły ziemie leżące na styku Wielkopolski, Pomorza Zachodniego i Brandenburgii $^{77}$, nie wzrastała liczebnie wskutek napływu młodzieży z innych regionów. W efekcie w tamtejszych rodzinach musiały się częściej pojawiać dzieci, które osiagnęły pełnoletność, a które nadal zamieszkiwały $\mathrm{z}$ rodzicami lub rodzicem, stanowiąc grupę pomocniczą $\mathrm{w}$ gospodarstwie rolnym. Ponadto wiele dzieci chłopskich najmowało się do pracy $\mathrm{w}$ charakterze robotników, jednakże z powodu trudnej sytuacji materialnej lub braku perspektyw dziedziczenia gospodarstwa nie wstępowało szybciej w zwiazki małżeńskie, tak jak zapewne miało to miejsce w silnie uprzemysłowionej części Westfalii i Nadrenii. Sytuacja ta - jak można przypuszczać - prowadziła do zwiększenia zasobu indywidualnych wnioskodawców. Jest to oczywiście hipoteza, która wymaga zweryfikowania. Przemawia za nią to, że wśród polskich optantów wnioskodawców, o których Konsulat Generalny w Berlinie przekazał informacje władzom niemieckim w 1924 r., aż 30\% i 26,3\% stanowili kolejno robotnicy i rolnicy - dodajmy: w zdecydowanej większości pochodzący ze wsi $(79,1 \% \text { i } 89,8 \%)^{78}$.

Jak już wspomniano, dane o optantach pochodzące z konsulatu w Essen w porównaniu z informacjami z Konsulatu Generalnego RP

75 D. Szudra i in., dz. cyt., s. 29.

${ }^{76}$ E. Spevack, Borderland Nationalism, Westward Migration, and Anti-Polish Aggression. The Case of the Grenzmark Posen-Westpreussen, 1919-1939, „East European Quarterly" 30, 1996, nr 3, s. 302 i in.

77 J. Mollenhauer, Wirtschafts- und bevölkerungspolitische Verhältnisse der nördlichen Grenzmark, Greifswald 1935, s. 133-138, 140-141; F. Ross, Die Grenzmark Posen-Westpreußen. Bevölkerung und Wirtschaft nach der territorialen Umgestalltung, „Deutsches Archiv für Landes- und Volksforschung” 3, 1939, nr 2, s. 393-396; J. Benyskiewicz, Demograficzne i gospodarcze położenie prowincji Grenzmark Posen-Westpreussen, „Zielonogórskie Zeszyty Muzealne” 2, 1971, s. 83-84, 87-88 [przedruk fragmentów pochodzących z wcześniejszej pracy tegoż autora: Położenie Polaków w Marchii Granicznej w latach 1919-1943, Zielona Góra 1968].

${ }^{78}$ D. Szudra i in., dz. cyt., s. 30-31. 
w Berlinie zawierają bardziej szczegółowe dane dotyczące miejsca zamieszkania. Wykorzystanie ich pozwala zredukować wstępnie założony zbiór 483 gospodarstw domowych do liczby 434, a zatem o 10,1\% (zob. tab. 6b). W efekcie przeprowadzonej weryfikacji istotnie na znaczeniu stracił „samotny” typ 1_c, gdyż jego udział obniżył się do $24,2 \%$, na wartości zyskał zaś jeszcze bardziej „pełno rodzinny” typ 3_b, osiagając poziom 59,7\%. Oba stanowiły aż 83,9\% w ogólnej liczbie gospodarstw jednoosobowych i rodzinnych optantów. Sam ten fakt nie powinien budzić zdziwienia, zastanawia jednak wysoki udział gospodarstw jednoosobowych, nawet jeśli jest o wiele niższy w porównaniu $\mathrm{z}$ odnotowanym dla Pogranicza. Dlaczego? Z pewnością wynika to z tego, że przeciętna dla całego (sic!) typu 1_ według danych z powszechnego spisu ludności z czerwca 1925 r. wyniosła dla Westfalii tylko 3,2\%, tj. najmniej w porównaniu z wszystkimi częściami Rzeszy Niemieckiej, dla Nadrenii zaś nieco więcej - 5,4\%, przy przeciętnej dla całego państwa równej $6,7 \%^{79}$. I choć z perspektywy metodycznej tego rodzaju porównanie może być kwestionowane, to jednak daje ono pewna podstawę do wnioskowania, że wśród osób optujących na rzecz Polski w okręgu konsularnym Essen było stosunkowo wiele takich, które nie założyły rodziny. Innymi słowy, prowadzenie w pojedynkę gospodarstwa domowego sprzyjało podjęciu decyzji o emigracji do kraju ojczystego. Oczywiście $\mathrm{w}$ nowoczesnych ruchach wędrówkowych przewagę nad uczestniczącymi w nich rodzinami zyskuja indywidualne osoby ${ }^{80}$, co również można było zaobserwować w Niemczech na przełomie XIX i XX w. na przykładzie strukturalnej zmiany $\mathrm{w}$ emigracji zamorskiej ${ }^{81}$. W tym kontekście późne wychodźstwo z Zagłębia Ruhry do odrodzonej Polski jawi się jako tradycyjne, choć należy też pamiętać, że na jego kształt silny wpływ wywarła sama specyfika funkcjonowania polskiej społeczności Westfalczyków, trudno integrującej się z niemiecką - co nie stało jednak na przeszkodzie w przejmowaniu określonych wzorców - tworzącej własną subkulturę i skupionej z reguły w zwartych narodowo koloniach górniczych ${ }^{82}$.

79 Statistik des Deutschen Reichs, t. 407 (Die Haushaltungen und Familien nach ihrer beruflichen und sozialen Gliederung), s. 11 (zestawienie: Die Einzeln- und Familienhaushaltungen im Deutschen Reichs in den Ländern und Landesteilen).

${ }^{80}$ Zob. np. D.K. Chojecki, Zróżnicowanie kierunków odptywu ludności z rolnictwa na Pomorzu Zachodnim w latach 1928-1929, „Zapiski Historyczne” 84, 2019, nr 2, s. 95 (mapa 2).

${ }^{81}$ P. Marschalck, Deutsche Überseewanderung im 19. Jahrhundert. Ein Beitrag zur soziologischen Theorie der Bevölkerung, Stuttgart 1973, s. 76-77.

${ }^{82}$ O. Steinert, dz. cyt., s. 71. 
Pewne aspekty kulturowe dotyczące badanej zbiorowości osób można ukazać w kontekście zagadnień związanych z antroponimami, które również wchodzą w krag zainteresowania demografii historycznej. Zacznijmy od tego, że 91,2\% interesujących nas wnioskodawców oraz żon wnioskodawców przed zawarciem związku małżeńskiego nosiło stricte polskie czy słowiańskie nazwiska. W większości przedstawiciele interesującej nas zbiorowości musieli się wywodzić z Wielkopolski, na co wskazuje występowanie obok Nowak nazwiska Kaczmarek ${ }^{83}$, jakże typowego dla poznaniaków ${ }^{84}$. Antroponim ten odnotowano u 8 wnioskodawców, a inne nazwiska pojawiały się rzadziej na wykazach.

O ile nazwiska optantów były w zasadzie stricte polskie czy słowiańskie, o tyle imiona, poddane silnemu wpływowi mody, już nie. Popularność określonych imion - przy zbliżonej liczbie ich podstawowych form: 56 i 59 - była większa u pełnoletnich mężczyzn (współczynnik Giniego 0,661) w porównaniu z pełnoletnimi kobietami $(0,584)$. Wśród pierwszych, biorac pod uwage mocne kryterium podziału zbioru, najczęściej, ze znaczna przewaga nad innymi, występowali Janowie (53), Józefowie (47), Franciszkowie (44) i Stanisławowie (43), którzy łącznie stanowili 46,1\% ogółu męskich wnioskodawców, natomiast w grupie drugich bezapelacyjnie dominowały Marianny (48), noszące to imię stanowiły 12,7\% ogółu wnioskodawczyń i żon. Dopiero dalsze miejsca, zastosowawszy do wydzielania zbioru umiarkowane kryterium, zajmowały Katarzyny (26), Franciszki (23) i Marie (23), które stanowiły 19,1\% ogółu omawianej grupy kobiet. Dodajmy, że najpopularniejszymi imionami słowiańskimi noszonymi przez dorosłych optantów były: Władysław (11) i Bronisława (7). W kontekście przedstawionych danych jako oczywisty jawi się fakt najczęstszego występowania wśród par małżeńskich Józefów i Mariann (8) oraz Janów i Mariann (6), jednakże stopień koncentracji konfiguracji imion współmałżonków był słaby (współczynnik Giniego 0,226), głównie z powodu większej gry możliwości.

${ }^{83}$ Zob. też M. Kowalski, P. Śleszyński, Migracje Polaków do Niemiec w świetle częstotliwości wystepowania najbardziej popularnych polskich nazwisk, „Przegląd Zachodni” 2010, nr 2, s. 123, 125 (kartogram częstości występowania nazwiska Kaczmarek), 128 (tab. 4. Charakterystyka porównawcza 20 najczęściej występujących polskich nazwisk w Polsce i Niemczech). Dla Zagłębia Ruhry dysponujemy dwutomowa praca poświęcona polskim nazwiskom, dla której podstawę źródłową stanowiły książki telefoniczne: Lexikon der Familiennamen polnischer Herkunft im Ruhrgebiet, t. 1, red. K. Rymut, J. Hoffman, Kraków 2006; t. 2, red. K. Rymut, J. Hoffman, oprac. B. Czopek-Kopciuch i in., Kraków 2010.

${ }^{84} \mathrm{http}: / /$ nlp.actaforte.pl:8080/Nomina/Ndistr?nazwisko=Kaczmarek\&join=on\&rel=on (7 XII 2019). Mapa tematyczna i wykaz częstości względnych dla powiatów generowane na podstawie występowania nazwiska w bazie PESEL. 
Niepełnoletni chłopcy i dziewczęta nie wykazywali różnic w stopniu skupienia podstawowych form imion (kolejno: 0,634 i 0,630) i pod tym względem byli zbliżeni do dorosłych mężczyzn. Niemniej jednak katalog imion był znacznie większy u chłopców (76) w porównaniu z dziewczynami (67), przy czym imiona chłopców w większym stopniu korespondowały z imionami dorosłych mężczyzn. W grupie bowiem młodszych na pierwsze miejsce, w innej konfiguracji, wysunęli się również Franciszkowie (58), Janowie (50), Józefowie (42) i Stanisławowie (34), którzy stanowili łącznie 36,9\% ogółu chłopców. Uwzględniwszy mocne kryterium podziału, przy tendencji spadkowej liczebności imiona te utworzyły odrębne jednoelementowe zbiory, co także odróżniało je od tego, co zaobserwowano w odniesieniu do pełnoletnich mężczyzn, których cztery najczęściej występujące imiona - dla przypomnienia - weszły w skład jednego zbioru. Tak czy inaczej w przypadku męskiego imiennictwa optantów możemy mówić o pewnej pośredniej replikacji. Nie da się już jednak tego powiedzieć w odniesieniu do kobiet. Dlaczego? Jak pamiętamy, wśród wnioskodawczyń i żon zdecydowanie dominowały Marianny, następnie Katarzyny, Franciszki i Marie. Natomiast wśród niepełnoletnich dziewczyn na pierwsze miejsce wysunęły się Marie (41), dalej zaś, stosując mocne kryterium podziału zbioru: Heleny (35) i Marianny (34), następnie Anny (26) i Jadwigi (26), które łącznie stanowiły 36,5\% ogółu dzieci płci żeńskiej, na które rozciagało się prawo opcji. W grupie młodszych liderek imienniczych nie pojawiły się zatem ani Franciszki (13 wystapień; 12. lokata), ani Katarzyny $(6 ; 20)$, podczas gdy Heleny, Anny i Jadwigi wysunęły się tu na czoło. Szczególny awans, by tak rzec, wywalczyło sobie imię Helena, biorąc pod uwagę fakt, że w zasobie wnioskodawczyń i żon pojawiło się ono tylko 9 razy i zajmowało odległe 14. miejsce. Być może popularność tego imienia należy łączyć ze zwiększoną recepcją czytelnicza ${ }^{85}$ powieści Ogniem $i$ mieczem Henryka Sienkiewicza, w której na pierwszy plan wysuwa się fikcyjna postać pięknej Heleny Skrzetuskiej z domu Kurcewicz, czy ze sławą zmarłej w 1909 r. Heleny Modrzejewskiej, wybitnej i urzekajaccej aktorki, podziwianej zapewne przez część starszej generacji optantów.

Powyższa analiza odnosiła się do wszystkich niepełnoletnich dzieci optantów, bez względu na to, w jakiej kolejności przychodziły one na świat. Niestety nie wiadomo, czy imiona dzieci w okólniku były podane według zasady starszeństwa. Trudno jest też odnaleźć klucz dla kolejności, według której na wykazie znaleźli się poszczególni wnioskodawcy,

${ }^{85}$ Wzmiankują o czytelnictwie: W. Skóra, dz. cyt., s. 522-523; J. Kozłowski, dz. cyt., s. 154 . 
podobnie zreszta jak w przypadku zestawień pochodzących z Konsulatu Generalnego RP w Berlinie, i to mimo że na tych ostatnich podano daty złożenia opcji. Nie można wykluczyć, że była w tym jakaś metoda, mająca za zadanie utrudnić drugiej stronie wyszukiwanie osób na wykazie. Skądinąd, przyjmując genderowe założenie, że przy większym znaczeniu płci męskiej imiona niepełnoletnich pierworodnych chłopców posiadających rodzeństwo powinny się częściej znajdować na pierwszej pozycji wśród wykazanych dzieci - można dowieść brak roli tego czynnika kulturowego. Na 100 niepełnoletnich dziewczyn w rzeczonej grupie przypadało bowiem „tylko” 102-103 niepełnoletnich chłopców; nieznaczna przewaga płci męskiej nad żeńską była jak najbardziej naturalna, biorąc pod uwagę prawidłowość demograficzna, która mówi o przychodzeniu na świat większej liczby chłopców niż dziewczynek (wskaźnik maskulinizacji urodzeń 105-106) i topnieniu tej przewagi z upływem czasu (ówcześnie wyrównanie się proporcji płci następowało ok. 20. roku życia), co dowodzi też wiarygodności analizowanego materiału.

\section{Konkluzje}

Główna fala późnego napływu polskich optantów z Niemiec do Polski, która miała miejsce w lipcu 1925 r., składała się głównie z reemigrantów pochodzących z Zagłębia Ruhry. Opisanie ich cech demograficznych w kontekście strukturalnym było możliwe na podstawie szczegółowego wykazu imiennego, przygotowanego przez polskie władze konsularne w ramach ustaleń zawartych w polsko-niemieckiej konwencji wiedeńskiej. Wprawdzie to główne źródło do poznania interesujących nas zagadnień demograficznych nie objęło wszystkich optantów, którzy przenieśli się do Polski we wspomnianym czasie lub zostali do niej wydaleni wskutek działań retorsyjnych, związanych z tzw. Optantenkrieg, to jednak możemy przyjąć, że analizowane dane o 1727 osobach objętych opcją na podległym obszarze konsulatu w Essen w miarę dobrze aproksymuja rzeczone zjawisko, zważywszy, że odnoszą się do tych, którzy rzeczywiście zamierzali opuścić Zagłębie Ruhry i w zdecydowanej większości przenieść się do Wielkopolski. Otrzymane wyniki, ze względu na „niebadawcze" przeznaczenie listy optantów, nie sa dokładne, ale z pewnością pozwalają ukazać obraz tendencji strukturalnych w myśl, że lepsza jakakolwiek wiedza przybliżająca do prawdy niż jej kompletny brak.

Zastosowawszy metodę kartograficzna, agregatywną (z dokonaniem weryfikacji rodzin) i porównawczą oraz wykorzystawszy procedurę Hellwiga i Giniego, wykazano, że polscy optanci, jakkolwiek rekrutowali się 
z całego obszaru Zagłębia Ruhry, to jednak gros z nich zamieszkiwało na południe od linii rzeki Emschery, głównie w Duisburgu-Hamm, wiążąc przede wszystkim swój byt z praca w górnictwie, rzadziej hutnictwie. Zbiorowość optantów była zmaskulinizowana głównie „za sprawa” indywidualnych wnioskodawców, co zapewne pozostawało w związku ze specyfika młodego napływu migracyjnego do centrum przemysłu ciężkiego. Niemniej jednak na tle innych przebadanych odznaczała się ona wysokim stopniem dzietności (fenomen związany z prokreacyjnym zachowaniem górników) i rodzinności, biorąc pod uwagę przeważający udział gospodarstw domowych tworzonych przez małżeństwa lub rodziców i dzieci. Zarówno dorośli, jak i dzieci rzadko nosili imiona, których etymologia wskazywałaby na słowiańskie pochodzenie, natomiast wśród nazwisk na pierwszym miejscu występowało charakterystyczne dla Wielkopolski Kaczmarek obok powszechnego Nowak. Imiona w większym stopniu podlegały modzie u płci pięknej, co ukazano, analizując podobieństwa i różnice w ich częstości, skupieniu i lokacie w odniesieniu do pełnoletnich kobiet i niepełnoletnich dziewczyn. Pomimo zaobserwowania pośredniej replikacji imion męskich nie stwierdzono wpływu czynnika kulturowego na porządek ich występowania w źródle, wskazując, że miał on charakter losowy lub uporządkowany ze względu na zasadę starszeństwa. Tego ostatniego nie można wprawdzie dowieść, ale wydaje się, że można byłoby zweryfikować, sięgnąwszy po indywidualną dokumentację wnioskową przechowywaną w Archiwum Akt Nowych ${ }^{86}$. Jej wykorzystanie, zważywszy na szerszy zestaw danych demograficznych (zob. wzór wniosku polskiego i niemieckiego), zapewne pozwoliłoby uściślić nakreślone tu aspekty demograficzne interesującego nas zjawiska.

${ }^{86}$ AAN, Ambasada RP w Berlinie, sygn. 3530, Optanci polscy w Westfalii. Kwestionariusze osobowe. Nazwiska na litery A-Ł, 1925 r., 506 ss.; tamże, sygn. 3531, Optanci polscy w Westfalii. Kwestionariusze osobowe. Nazwiska na litery M-Z, 1925 r., 544 ss. 


\section{Aneks}

Tabela 1. Liczba polskich optantów w okręgu konsularnym Essen według gmin w grudniu $1924 \mathrm{r}$.

\begin{tabular}{|c|c|c|c|c|c|}
\hline \multirow[b]{2}{*}{ Gmina } & \multirow[b]{2}{*}{$\begin{array}{l}\text { Wniosko- } \\
\text { dawcy }\end{array}$} & \multicolumn{4}{|c|}{$\begin{array}{c}\text { Wnioskodawcy i osoby, na które rozciąga się } \\
\text { prawo opcji }\end{array}$} \\
\hline & & mężczyźni & kobiety & ogółem & $\begin{array}{l}\text { ogólem } \\
\text { w promi- } \\
\text { lach liczby } \\
\text { ludności } \\
\text { gminy }\end{array}$ \\
\hline Duisburg-Hamborn & 108 & 200 & 186 & 386 & 0,9 \\
\hline Oberhausen & 54 & 86 & 96 & 182 & 1,0 \\
\hline Gelsenkirchen & 53 & 92 & 79 & 171 & 0,5 \\
\hline Essen & 46 & 75 & 80 & 155 & 0,2 \\
\hline Dortmund & 40 & 77 & 54 & 131 & 0,2 \\
\hline Recklinghausen & 23 & 42 & 47 & 89 & 1,1 \\
\hline Herne & 27 & 42 & 42 & 84 & 0,9 \\
\hline Castrop-Rauxel & 23 & 41 & 39 & 80 & 1,5 \\
\hline Gladbeck & 11 & 34 & 21 & 55 & 0,9 \\
\hline Bottrop & 12 & 27 & 25 & 52 & 0,6 \\
\hline Bochum & 12 & 21 & 13 & 34 & 0,1 \\
\hline Rünthe & 6 & 17 & 15 & 32 & 5,5 \\
\hline Wattenscheid & 6 & 17 & 13 & 30 & 0,5 \\
\hline Marl & 6 & 19 & 9 & 28 & 1,0 \\
\hline Wanne-Eickel & 5 & 16 & 12 & 28 & 0,3 \\
\hline Oer-Erkenschwick & 6 & 13 & 14 & 27 & 1,8 \\
\hline Lünen & 6 & 10 & 7 & 17 & 0,4 \\
\hline Herten & 6 & 9 & 6 & 15 & 0,4 \\
\hline Mülheim & 3 & 7 & 6 & 13 & 0,1 \\
\hline Hamm & 1 & 5 & 4 & 9 & 0,2 \\
\hline Wischerhöfen & 2 & 4 & 5 & 9 & 1,5 \\
\hline Witten & 3 & 4 & 5 & 9 & 0,1 \\
\hline Altenbögge & 2 & 5 & 3 & 8 & 1,8 \\
\hline Bergkamen & 2 & 3 & 5 & 8 & 1,1 \\
\hline Datteln & 1 & 4 & 4 & 8 & 0,4 \\
\hline Selm & 1 & 5 & 3 & 8 & 0,7 \\
\hline Welper & 2 & 2 & 6 & 8 & 1,3 \\
\hline
\end{tabular}




\begin{tabular}{|c|c|c|c|c|c|}
\hline \multirow[b]{2}{*}{ Gmina } & \multirow[b]{2}{*}{$\begin{array}{l}\text { Wniosko- } \\
\text { dawcy }\end{array}$} & \multicolumn{4}{|c|}{$\begin{array}{c}\text { Wnioskodawcy i osoby, na które rozciąga się } \\
\text { prawo opcji }\end{array}$} \\
\hline & & mężczyźni & kobiety & ogółem & $\begin{array}{c}\text { ogółem } \\
\text { w promi- } \\
\text { lach liczby } \\
\text { ludności } \\
\text { gminy }\end{array}$ \\
\hline Kamen & 1 & 6 & 1 & 7 & 0,6 \\
\hline $\begin{array}{l}\text { Bramm- } \\
\text {-Ostwennemar }\end{array}$ & 1 & 2 & 4 & 6 & 2,3 \\
\hline Hagen & 2 & 4 & 2 & 6 & 0,0 \\
\hline Waltrop & 2 & 2 & 4 & 6 & 0,5 \\
\hline Dinslaken & 1 & 4 & 1 & 5 & 0,2 \\
\hline Horneburg & 1 & 3 & 2 & 5 & 6,9 \\
\hline Walsum & 1 & 2 & 3 & 5 & 0,2 \\
\hline Wetter & 1 & 4 & 1 & 5 & 0,5 \\
\hline Düsseldorf & 2 & - & 2 & 2 & 0,0 \\
\hline Wuppertal & 2 & 1 & 1 & 2 & 0,0 \\
\hline Hattingen & 1 & 1 & - & 1 & 0,1 \\
\hline Neuß & 1 & - & 1 & 1 & 0,0 \\
\hline Razem & 483 & 906 & 821 & 1727 & 0,4 \\
\hline
\end{tabular}

Źródło: oprac. własne na podstawie: APSz, Rejencja Szczecińska, Wydział Prezydialny, sygn. 9825, k. 112-118; Gemeindelexikon für den Staat Preussen, t. 11: Provinz Westfalen. Nach dem endgültigen Ergebnis der Volkszählung vom 16. Juni 1925 und anderen amtlichen Quellen unter Zugrundelegung des Gebietsstandes vom 1. März 1931, oprac. Preußischen Statistischen Landesamt, Berlin 1931, s. 1-109; Gemeindelexikon für den Staat Preussen, t. 13: Provinz Rheinprovinz. Nach dem endgültigen Ergebnis der Volkszählung vom 16. Juni 1925 und anderen amtlichen Quellen unter Zugrundelegung des Gebietsstandes vom 1. Dezember 1930, oprac. Preußischen Statistischen Landesamt, Berlin 1930, s. 1-202.

Tabela 2. Liczba polskich optantów w okręgu konsularnym Essen według prowincji, rejencji i powiatów w grudniu $1924 \mathrm{r}$.

\begin{tabular}{|l|c|c|c|c|}
\hline \multirow{2}{*}{ Prowincja/rejencja/powiat } & \multirow{2}{*}{$\begin{array}{c}\text { Wniosko- } \\
\text { dawcy }\end{array}$} & \multicolumn{3}{|c|}{$\begin{array}{c}\text { Wnioskodawcy i osoby, na które } \\
\text { rozciąga się prawo opcji }\end{array}$} \\
\cline { 3 - 5 } & & mężczyźni & kobiety & ogólem \\
\hline Nadrenia & $\mathbf{2 1 8}$ & $\mathbf{3 7 5}$ & $\mathbf{3 7 6}$ & $\mathbf{7 5 1}$ \\
\hline Düsseldorf & $\mathbf{2 1 8}$ & $\mathbf{3 7 5}$ & $\mathbf{3 7 6}$ & $\mathbf{7 5 1}$ \\
\hline Dinslaken & 2 & 6 & 4 & 10 \\
\hline Duisburg-Hamborn (miejski) & 108 & 200 & 186 & 386 \\
\hline Düsseldorf (miejski) & 2 & - & 2 & 2 \\
\hline Essen (miejski) & 46 & 75 & 80 & 155 \\
\hline Mülheim a.d. Ruhr (miejski) & 3 & 7 & 6 & 13 \\
\hline
\end{tabular}




\begin{tabular}{|c|c|c|c|c|}
\hline \multirow{2}{*}{ Prowincja/rejencja/powiat } & \multirow{2}{*}{$\begin{array}{l}\text { Wniosko- } \\
\text { dawcy }\end{array}$} & \multicolumn{3}{|c|}{$\begin{array}{l}\text { Wnioskodawcy i osoby, na które } \\
\text { rozciąga się prawo opcji }\end{array}$} \\
\hline & & mężczyźni & kobiety & ogółem \\
\hline Neuß (miejski) & 1 & - & 1 & 1 \\
\hline Oberhausen (miejski) & 54 & 86 & 96 & 182 \\
\hline Wuppertal (miejski) & 2 & 1 & 1 & 2 \\
\hline Westfalia & 265 & 531 & 445 & 976 \\
\hline Arnsberg & 144 & 286 & 234 & 520 \\
\hline Bochum (miejski) & 12 & 21 & 13 & 34 \\
\hline Castrop-Rauxel (miejski) & 23 & 41 & 39 & 80 \\
\hline Dortmund (miejski) & 40 & 77 & 54 & 131 \\
\hline Ennepe-Ruhrkreis & 3 & 3 & 6 & 9 \\
\hline Hagen (miejski) & 2 & 4 & 2 & 6 \\
\hline Hamm (miejski) & 1 & 5 & 4 & 9 \\
\hline Herne (miejski) & 27 & 42 & 42 & 84 \\
\hline Lüdenscheid & 1 & 5 & 3 & 8 \\
\hline Lünen (miejski) & 6 & 10 & 7 & 17 \\
\hline Unna & 14 & 37 & 33 & 70 \\
\hline Wanne-Eickel (miejski) & 5 & 16 & 12 & 28 \\
\hline Wattenscheid (miejski) & 6 & 17 & 13 & 30 \\
\hline Wetter & 1 & 4 & 1 & 5 \\
\hline Witten (miejski) & 3 & 4 & 5 & 9 \\
\hline Münster & 121 & 245 & 211 & 456 \\
\hline Bottrop (miejski) & 12 & 27 & 25 & 52 \\
\hline Gelsenkirchen & 6 & 9 & 6 & 15 \\
\hline Gelsenkirchen (miejski) & 53 & 92 & 79 & 171 \\
\hline Gladbeck (miejski) & 11 & 34 & 21 & 55 \\
\hline Recklinghausen & 16 & 41 & 33 & 74 \\
\hline Recklinghausen (miejski) & 23 & 42 & 47 & 89 \\
\hline Razem & 483 & 906 & 821 & 1727 \\
\hline
\end{tabular}

Źródło: oprac. własne na podstawie: APSz, Rejencja Szczecińska, Wydział Prezydialny, sygn. 9825, k. 112-118; Gemeindelexikon für den Staat Preussen, t. 11: Provinz Westfalen. Nach dem endgültigen Ergebnis der Volkszählung vom 16. Juni 1925 und anderen amtlichen Quellen unter Zugrundelegung des Gebietsstandes vom 1. März 1931, oprac. Preußischen Statistischen Landesamt, Berlin 1931, s. 1-109; Gemeindelexikon für den Staat Preussen, t. 13: Provinz Rheinprovinz. Nach dem endgültigen Ergebnis der Volkszählung vom 16. Juni 1925 und anderen amtlichen Quellen unter Zugrundelegung des Gebietsstandes vom 1. Dezember 1930, oprac. Preußischen Statistischen Landesamt, Berlin 1930, s. 1-202. 
Tabela 3. Liczba polskich optantów w okręgu konsularnym Essen według wielkości gmin w grudniu $1924 \mathrm{r}$.

\begin{tabular}{|c|c|c|c|c|c|c|}
\hline \multicolumn{2}{|c|}{ Gminy z optantami } & \multirow[b]{2}{*}{$\begin{array}{c}\text { Liczba } \\
\text { wniosko- } \\
\text { dawców }\end{array}$} & \multicolumn{4}{|c|}{$\begin{array}{c}\text { Wnioskodawcy i osoby, na które rozciąga się } \\
\text { prawo opcji }\end{array}$} \\
\hline wielkość & $\begin{array}{l}\text { liczeb- } \\
\text { ność }\end{array}$ & & $\begin{array}{l}\text { mężz- } \\
\text { czyźni }\end{array}$ & kobiety & ogółem & $\begin{array}{c}\text { ogółem } \\
\text { w promi- } \\
\text { lach lud- } \\
\text { ności gmin } \\
\text { z optantami }\end{array}$ \\
\hline$<2000$ & 1 & 1 & 2 & 3 & 5 & 6,9 \\
\hline $2000-5000$ & 2 & 3 & 8 & 9 & 17 & 2,4 \\
\hline $5000-10000$ & 5 & 14 & 33 & 25 & 58 & 1,7 \\
\hline $10000-20000$ & 5 & 12 & 18 & 16 & 34 & 0,5 \\
\hline $20000-50000$ & 7 & 22 & 48 & 40 & 88 & 0,4 \\
\hline $50000-100000$ & 9 & 113 & 215 & 199 & 414 & 0,6 \\
\hline$\geq 100000$ & 10 & 318 & 582 & 529 & 1111 & 0,3 \\
\hline Razem & 39 & 483 & 906 & 821 & 1727 & 0,4 \\
\hline
\end{tabular}

Źródło: oprac. własne na podstawie: APSz, Rejencja Szczecińska, Wydział Prezydialny, sygn. 9825, k. 112-118; Gemeindelexikon für den Staat Preussen, t. 11: Provinz Westfalen. Nach dem endgültigen Ergebnis der Volkszählung vom 16. Juni 1925 und anderen amtlichen Quellen unter Zugrundelegung des Gebietsstandes vom 1. März 1931, oprac. Preußischen Statistischen Landesamt, Berlin 1931, s. 1-109; Gemeindelexikon für den Staat Preussen, t. 13: Provinz Rheinprovinz. Nach dem endgültigen Ergebnis der Volkszählung vom 16. Juni 1925 und anderen amtlichen Quellen unter Zugrundelegung des Gebietsstandes vom 1. Dezember 1930, oprac. Preußischen Statistischen Landesamt, Berlin 1930, s. 1-202.

Tabela 4. Liczba polskich optantów (wnioskodawcy) w okręgu konsularnym Essen według zawodów w grudniu $1924 \mathrm{r}$.

\begin{tabular}{|l|c|c|c|c|c|}
\hline \multirow{2}{*}{ Zawód } & \multicolumn{2}{c|}{ Kod / Klasa } & \multicolumn{3}{c|}{ Liczba wnioskodawców } \\
\cline { 2 - 6 } & HISCO & HISCLASS & ogółem & $\begin{array}{c}\text { w tym } \\
\text { kobiety }\end{array}$ & \% ogólem \\
\hline górnik & $7-11.05$ & 9 & 198 & - & 41,3 \\
\hline robotnik & $9-99.00$ & 11 & 78 & 5 & 16,3 \\
\hline brak danych & - & - & 44 & 39 & 9,2 \\
\hline hutnik & $7-20.00$ & 9 & 39 & - & 8,1 \\
\hline maszynista & $9-69.10$ & 9 & 20 & - & 4,2 \\
\hline ślusarz & $8-39.30$ & 7 & 11 & - & 2,3 \\
\hline kupiec & $4-10.20 / 30$ & $3 / 4$ & 10 & - & 2,1 \\
\hline krawiec & $7-91.00$ & 7 & 9 & 4 & 1,9 \\
\hline (wdowa) & - & - & 8 & 8 & 1,7 \\
\hline służąca & $5-40.10$ & 9 & 7 & 7 & 1,5 \\
\hline ekspedientka & $4-51.30$ & 5 & 6 & 6 & 1,3 \\
\hline
\end{tabular}




\begin{tabular}{|l|c|c|c|c|c|}
\hline \multirow{2}{*}{ Zawód } & \multicolumn{2}{|c|}{ Kod Klasa } & \multicolumn{2}{c|}{ Liczba wnioskodawców } \\
\cline { 2 - 6 } & HISCO & HISCLASS & ogólem & $\begin{array}{c}\text { w tym } \\
\text { kobiety }\end{array}$ & \% ogółem \\
\hline palacz & $9-69.30$ & 9 & 5 & - & 1,0 \\
\hline piekarz & $7-76.10$ & 7 & 5 & - & 1,0 \\
\hline kowal & $8-80.10$ & 7 & 4 & - & 0,8 \\
\hline szewc & $8-01.10$ & 7 & 4 & - & 0,8 \\
\hline cieśla & $9-54.10$ & 7 & 3 & - & 0,6 \\
\hline koksiarz & $7-49.20$ & 9 & 3 & - & 0,6 \\
\hline murarz & $9-51.20$ & 7 & 3 & - & 0,6 \\
\hline stelmach & $8-19.25$ & 7 & 3 & - & 0,6 \\
\hline tokarz & $8-33.20$ & 7 & 3 & - & 0,6 \\
\hline kolejarz & $9-99.99$ & - & 2 & - & 0,4 \\
\hline modystka & $7-93.20$ & 7 & 2 & 2 & 0,4 \\
\hline bez zawodu & - & - & 1 & 1 & 0,2 \\
\hline bioenergoterapeuta & - & - & 1 & - & 0,2 \\
\hline agent handlowy & $4-32.20$ & 4 & 1 & - & 0,2 \\
\hline dekarz & $9-53.00$ & 9 & 1 & - & 0,2 \\
\hline destylator & $7-44.90$ & 9 & 1 & - & 0,2 \\
\hline fryzjer & $5-70.25$ & 9 & 1 & 1 & 0,2 \\
\hline goniec & $3-70.40$ & 9 & 1 & - & 0,2 \\
\hline gospodarz & $6-11.10$ & 8 & 1 & - & 0,2 \\
\hline mleczarz & $4-10.30$ & 4 & 1 & - & 0,2 \\
\hline ogrodnik & $6-27.00$ & 12 & 1 & - & 0,2 \\
\hline opiekunka & $5-40.35$ & 9 & 1 & 1 & 0,2 \\
\hline owczarz & $6-24.30$ & 12 & 1 & - & 0,2 \\
\hline rzeźnik & $7-73.10$ & 7 & 1 & - & 0,2 \\
\hline Razem & - & - & 480 & 74 & 100,0 \\
\hline
\end{tabular}

Źródło: oprac. własne na podstawie: APSz, Rejencja Szczecińska, Wydział Prezydialny, sygn. 9825, k. $112-118$. 
Tabela 5. Liczba polskich optantów w okręgu konsularnym Essen według statusu i form potencjalnej emigracji w grudniu $1924 \mathrm{r}$.

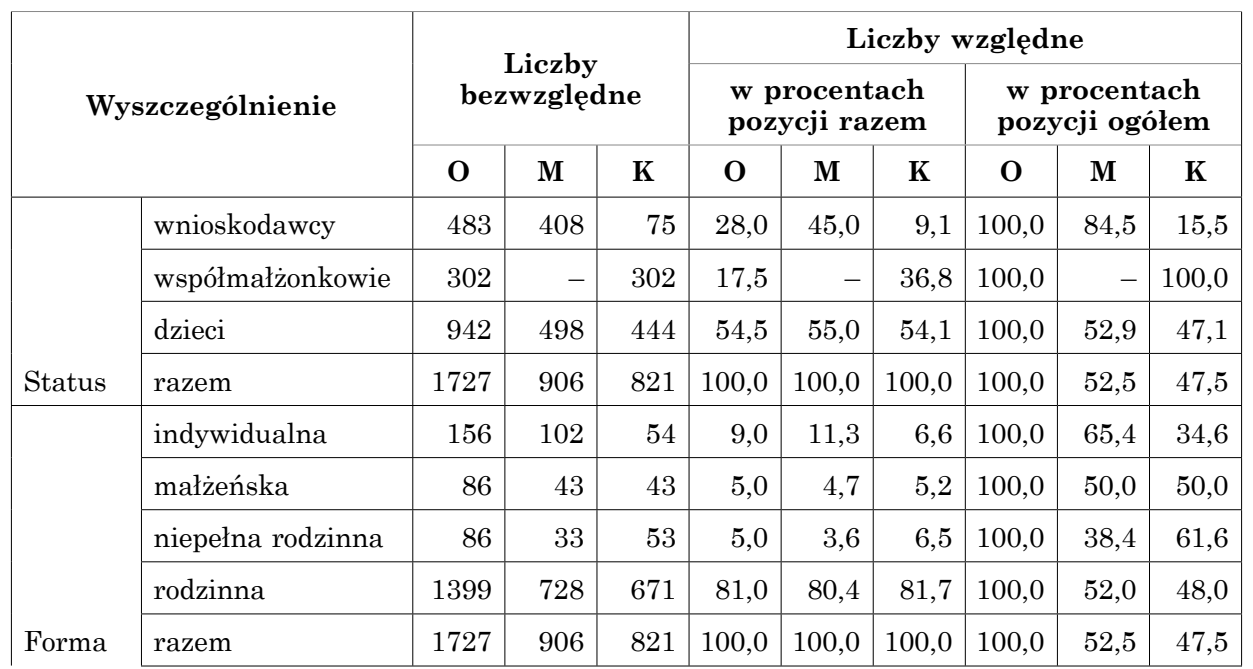

Legenda: O - ogółem, M - mężczyźni, K - kobiety.

Źródło: oprac. własne na podstawie: APSz, Rejencja Szczecińska, Wydział Prezydialny, sygn. 9825, k. $112-118$.

Tabela 6a. Liczba zakładanych typów gospodarstw domowych polskich optantów w okręgu konsularnym Essen w grudniu 1924 r.

\begin{tabular}{|l|l|r|r|}
\hline \multirow{2}{*}{ Typ* } & \multicolumn{2}{|c|}{ Gospodarstwo } & \multicolumn{2}{c|}{ Liczba gospodarstw } \\
\cline { 3 - 4 } & & bezwzględna & względna \\
\hline 1_b & osób samotnych stanu wdowiego & 2 & 0,4 \\
\hline 1_c & osób samotnych o nieznanym stanie cywilnym & 154 & 31,9 \\
\hline 2_a & rodzeństwa stanu wolnego & 2 & 0,4 \\
\hline 3_a & małżeństwa bezdzietnego & 43 & 8,9 \\
\hline 3_b & małżeństwa z dziećmi & 259 & 53,6 \\
\hline 3_c & wdowców z dziećmi & 2 & 0,4 \\
\hline 3_d & wdów z dziećmi & 16 & 3,3 \\
\hline 3_e & rodzica bez współmałżonka z dziećmi & 5 & 1,0 \\
\hline Razem & & 483 & 100,0 \\
\hline
\end{tabular}

Legenda: * Typologia Petera Lasletta zmodyfikowana przez Cezarego Kuklę.

Źródło: oprac. własne na podstawie: APSz, Rejencja Szczecińska, Wydział Prezydialny, sygn. 9825, k. $112-118$. 
Tabela 6b. Liczba zweryfikowanych typów gospodarstw domowych polskich optantów w okręgu konsularnym Essen w grudniu 1924 r.

\begin{tabular}{|c|c|c|c|}
\hline \multirow[b]{2}{*}{ Typ* } & \multirow[b]{2}{*}{ Gospodarstwo } & \multicolumn{2}{|c|}{ Liczba gospodarstw } \\
\hline & & $\begin{array}{c}\text { bez- } \\
\text { względna }\end{array}$ & względna \\
\hline 1_b & osób samotnych stanu wdowiego & 2 & 0,5 \\
\hline 1_c & osób samotnych o nieznanym stanie cywilnym & 105 & 24,2 \\
\hline 2_a; 2_a? & rodzeństwa stanu wolnego & 7 & 1,6 \\
\hline 3_a & małżeństwa bezdzietnego & 37 & 8,5 \\
\hline $3 \_b$ & małżeństwa z dziećmi & 259 & 59,7 \\
\hline 3_c & wdowców z dziećmi & 2 & 0,5 \\
\hline 3_d; 3_d? & wdów z dziećmi & 15 & 3,5 \\
\hline 3_e & rodzica bez współmałżonka z dziećmi & 3 & 0,7 \\
\hline 4_? & rodziny rozszerzonej & 4 & 0,9 \\
\hline Razem & & 434 & 100,0 \\
\hline
\end{tabular}

Legenda: * Typologia Petera Lasletta zmodyfikowana przez Cezarego Kuklę.

Źródło: oprac. własne na podstawie: APSz, Rejencja Szczecińska, Wydział Prezydialny, sygn. 9825, k. $112-118$.

Tabela 7. Liczba dzieci w rodzinach polskich optantów w okręgu konsularnym Essen w grudniu $1924 \mathrm{r}$.

\begin{tabular}{|l|c|c|c|c|}
\hline \multirow{2}{*}{ Liczba dzieci } & \multicolumn{4}{|c|}{ Liczba małzeństw lub rodzin } \\
\cline { 2 - 5 } & ogółem & w tym górnicy & w tym robotnicy & w tym hutnicy \\
\hline 0 & 43 & 19 & 6 & 6 \\
\hline 1 & 53 & 17 & 14 & 4 \\
\hline 2 & 48 & 20 & 6 & 5 \\
\hline 3 & 58 & 29 & 8 & 8 \\
\hline 4 & 52 & 29 & 8 & 4 \\
\hline 5 & 34 & 20 & 8 & 1 \\
\hline 6 & 25 & 13 & 5 & - \\
\hline 7 & 8 & 6 & - & 30 \\
\hline 8 & 4 & 2 & 1 & 73 \\
\hline Razem & 325 & 155 & 56 & 2,43 \\
\hline Liczba dzieci & 939 & 496 & 160 & 2,86 \\
\hline Średnia liczba dzieci & 2,89 & 3,20 & & \\
\hline
\end{tabular}

Źródło: oprac. własne na podstawie: APSz, Rejencja Szczecińska, Wydział Prezydialny, sygn. 9825, k. $112-118$. 


\section{Bibliografia}

Beiträge zum deutschen Bevölkerungsproblem. Der Geburtenrückgang im Deutschen Reich. Die allgemeine deutsche Sterbetafel für die Jahre 1924-1926, Berlin 1929 (Sonderhefte zu „Wirtschaft und Statistik”, 5).

Benyskiewicz J., Demograficzne $i$ gospodarcze położenie prowincji Grenzmark Posen-Westpreussen, „Zielonogórskie Zeszyty Muzealne” 2, 1971, s. 83-95.

Chojecki D.K., Optanci polscy w rejencji szczecińskiej $w$ świetle informacji Generalnego Konsulatu RP w Berlinie z przełomu lat 1921 i 1922, „Przeszłość Demograficzna Polski” 34, 2014, s. 89-101.

Chojecki D.K., Population Changes in Polish Western Territories Before and After World War I, „Historická demografie” 44, 2020, nr 1, s. 93-131.

Chojecki D.K., Zróżnicowanie kierunków odpływu ludności z rolnictwa na Pomorzu Zachodnim w latach 1928-1929, „Zapiski Historyczne” 84, 2019, nr 2, s. 83-122.

Feld W., Zur Geschlechtsgliederung der städtischen und ländlichen Bevölkerung, „Allgemeines Statistisches Archiv” 17, 1907, nr 1, s. 203-225.

Fihel A., Pteć a trwanie życia. Analiza demograficzna, Warszawa 2011.

Galloway P.R., Hammel E.A., Lee R.D., Fertility Decline in Prussia, 1875-1910. A Pooled Cross-Section Time Series Analysis, „Population Studies” 48, 1994, s. $135-158$.

Galloway P.R., Hammel E.A., Lee R.D., Urban versus Rural. Fertility Decline in the Cities and Rural Districts of Prussia, 1875 to 1910, „European Journal of Population" 14, 1998, s. 209-264.

Hamm B., Wprowadzenie do socjologii osadnictwa, tłum. A. Rosłan, Warszawa 1990.

Keller Z., Die Fremdsprachige Bevölkerung im Freistaate Preußen, „Zeitschrift des Preußischen Statistischen Landesamts" 66, 1926, s. 144-188.

Kiesewetter H., Industrielle Revolution in Deutschland 1815-1914, Frankfurt am Main 1989.

Köllmann W., Bevölkerung in der industriellen Revolution, Göttingen 1974.

Kowalski M., Śleszyński P., Migracje Polaków do Niemiec w świetle częstotliwości wystepowania najbardziej popularnych polskich nazwisk, „Przegląd Zachodni” 2010, nr 2, s. 115-130.

Kozłowski J., Zjednoczenie Zawodowe Polskie $i$ jego działalność w Zagłębiu Ruhry 1902-1939, w: Schimanski, Kuzorra i inni. Polacy w Zagłębiu Ruhry 1870/71-1945, red. J. Dahlmann, A.S. Kotowski, Z. Karpus, Toruń 2006, s. $133-162$.

Kuklo C., Demografia Rzeczypospolitej przedrozbiorowej, Warszawa 2009.

Kula W., Problemy i metody historii gospodarczej, Warszawa 1963.

Leeuwen M.H.D. van, Mass I., HISCLASS. A Historical International Social Class Scheme, Leuven 2011.

Leszczyńska C., Polish Emigration Abroad. Regional Structure and Streams of Emigration in the Years 1870-1914 and 1918-1939, „Przeszłość Demograficzna Polski” 41, 2019, s. 177-207. 
Marschalck P., Deutsche Überseewanderung im 19. Jahrhundert. Ein Beitrag zur soziologischen Theorie der Bevölkerung, Stuttgart 1973.

Matzerath H., Urbanisierung in Preußen 1815-1914, Stuttgart 1985.

Mollenhauer J., Wirtschafts- und bevölkerungspolitische Verhältnisse der nördlichen Grenzmark, Greifswald 1935.

Mombert P., Studien zur Bevölkerungsbewegung in Deutschland in den letzten Jahrzehnten mit besonderer Berücksichtigung der ehelichen Fruchtbarkeit, Karlsruhe 1907.

Murzynowska K., Polskie wychodźstwo zarobkowe w Zagtębiu Ruhry w latach 1880-1914, Wrocław 1972.

Nadobnik M., Wyludnianie sie wsi Wielkopolskiej, „Ruch Prawniczy, Ekonomiczny i Socjologiczny" 17, 1937, nr 1, s. 89*-100*.

Philippi M., Die Auswanderung und Einwanderung in Preußen im Jahre 1925, „Zeitschrift des Preußischen Statistischen Landesamts” 66, 1926, s. 377-397.

Piotrowski M., Reemigracja Polaków z Niemiec, 1918-1939, Lublin 2000.

Piotrowski M., Wychodźstwo polskie w Zagtębiu Ruhry jako faktor polsko-niemieckiej gry dyplomatycznej, w: Schimanski, Kuzorra i inni. Polacy w Zagtebiu Ruhry 1870/71-1945, red. J. Dahlmann, A.S. Kotowski, Z. Karpus, Toruń 2006, s. 196-223.

Praszałowicz D., Makowski K.A., Zięba A.A., Mechanizmy zamorskich migracji tańcuchowych $w$ XIX wieku: Polacy, Niemcy, Żydzi, Rusini. Zarys problemu, Kraków 2004.

Ravenstein E.G., The Laws of Migration, „Journal of the Statistical Society of London" 48, 1885, nr 2, s. 167-235.

Reulecke J., Geschichte der Urbanisierung in Deutschland, Frankfurt am Main 1985.

Ross F., Die Grenzmark Posen-Westpreußen. Bevölkerung und Wirtschaft nach der territorialen Umgestaltung, „Deutsches Archiv für Landes- und Volksforschung" 3, 1939, nr 2, s. 380-418.

Ruffié J., Seks i śmierć, tłum. B.A. Matusiak, Warszawa 1997.

Runge J., Metody badań w geografii spoteczno-ekonomicznej - elementy metodologii, wybrane narzędzia badawcze, Katowice 2007.

Skóra W., Stużba konsularna Drugiej Rzeczypospolitej. Organizacja, kadry i działalność, Torun 2006.

Spevack E., Borderland Nationalism, Westward Migration, and Anti-Polish Aggression. The Case of the Grenzmark Posen-Westpreussen, 1919-1939, „East European Quarterly” 30, 1996, nr 3, s. 301-330.

Stażewski M., Opcja ludności niemieckiej $w$ Wielkopolsce i na Pomorzu w latach dwudziestych, „Przegląd Zachodni” 1994, nr 1, s. 31-55.

Stażewski M., Przymusowy wyjazd z Polski optantów niemieckich $w 1925$ roku, „Studia Historica Gedanensia” 5, 2014, s. 31-55.

Steinert O., Tygiel vs. subkultura. Integracja polskich migrantów w Berlinie i w Zagtębiu Ruhry (1871-1918), w: Schimanski, Kuzorra i inni. Polacy $w$ Zagtębiu Ruhry 1870/71-1945, red. J. Dahlmann, A.S. Kotowski, Z. Karpus, Toruń 2006, s. 56-73. 
Sudra P., Zastosowanie wskaźników koncentracji przestrzennej $w$ badaniu procesów urban sprawl, „Przegląd Geograficzny” 88, 2016, nr 2, s. 247-272.

Szołtysek M., Toward a Conceptual Framework for the Variation in Historical Family and Household Systems Across Eurasia, „Przeszłość Demograficzna Polski” 36, 2014, s. 55-86.

Szudra D., Między obowiazkiem patriotycznym a koniecznościa ekonomiczna. Migracje w krainie „,krwawiacej granicy” (Provinz Grenzmark Posen-Westpreussen). Uwagi źródłowe, w: Tempus nostrum est. Księga pamiatkowa ofiarowana profesorowi Edwardowi Wtodarczykowi w 60. rocznice urodzin, red. D. Szudra, R. Techman, Szczecin 2006, s. 339-352.

Szudra D., Optanci polscy $w$ rejencji stralsundzkiej $w$ świetle informacji Generalnego Konsulatu RP $w$ Berlinie pochodzacych z przełomu lat 1921 i 1922, „Przegląd Zachodniopomorski” 21 (50), 2006, nr 2, s. 45-55.

Szudra D. i in., Optanci polscy w prowincji Marchia Graniczna Poznańskie-Prusy Zachodnie w świetle informacji Generalnego Konsulatu RP w Berlinie pochodzacych z przełomu lat 1921 i 1922, „Przegląd Zachodniopomorski” 20 (49), 2005, nr 3, s. 21-33.

Weyer-von Schoultz M., Stadt und Gesundheit im Ruhrgebiet 1850-1929. Verstädterung und kommunale Gesundheitspolitik am Beispiel der jungen Industriestadt Gelsenkirchen, Essen 1994.

\section{Dariusz K. Chojecki}

Polish optants from the Ruhr region in 1924. Demographic aspects (Summary)

The rebuilding of the Polish state after World War I was accompanied by masses of people returning to the country. One of the largest groups of Polish repatriates came from the Ruhr region. The paper seeks to define the characteristics of this stream of migrants in terms of its demographic composition and structure on the basis of personal data published in the Prussian ministry circulaire. As it had been draw up purely for administrative purposes, the source required a broader critical analysis. In order to paint a picture of the subpopulation of optants from the Polish consular district in Essen, the author uses first and foremost the aggregate method and presents the outcome of grouping performed with the tools used in earlier papers on the Polish optants in the Frontier March (Grenzmark) and Western Pomerania. The principal auxiliary source were municipality lexicons from the province of Westphalia and Rhine. The research has made it possible to draw conclusions concerning such issues as the spatial distribution of people applying for Polish citizenship, including the main centres of Polish optants (Duisburg followed by Oberhausen, Gelsenkirchen, Essen, and Dortmund); social and professional structure of the optants (predominance of miners and people with lower-grade professional qualifications); nature of potential migration (great percentage of family migrations as compared to other researched consular 
districts); level of feminisation of individual optants (noticeable predominance of men over women); fertility rate among the families of applicants (the highest among all researched consular districts, especially due to procreative activities among the miner population); issues concerning anthroponyms among adults and children (optants possibly hailing from Greater Poland [Wielkopolska]; abandoning typically Polish or Slavic names; greater concentration of certain names among men and boys; greater susceptibility to changes in the selection of names among women in connection with observed divergences in the pool of names borne by minor girls). The outcome of the analysis reviewed in the paper and its interpretation should be seen as a preliminary discussion of the issue in question. The themes tackled in the article need to be expounded upon with the analysis of personal files of the optants stored in the Central Archive of Modern Records in Warsaw.

Dariusz K. Chojecki - historyk i demograf, pracownik Instytutu Historycznego Uniwersytetu Szczecińskiego, związany z uczelnią od 1995 r. Swoje zainteresowania naukowe koncentruje na dziejach ludności tzw. Wielkiego Niemieckiego Wschodu (wschodnie prowincje Prus), w tym Pomorza Zachodniego (Provinz Pommern) i Szczecina w XIX i pierwszej połowie XX stulecia. Jego domeną badawczą są procesy demograficzne rozpatrywane w kontekście przemian społecznych zachodzących w dobie wielkiej transformacji demograficznej. W badaniach łączy wykorzystanie źródeł (i metod) o charakterze ilościowym ze źródłami jakościowymi. W 2002 r. obronił rozprawę doktorską na temat Ludność pruskiej prowincji Pomorze w latach 1919-1939. Przemiany $w$ ruchu naturalnym i migracyjnym. W 2014 r. otrzymał stopień doktora habilitowanego, wskazując jako główne osiagnięcie książkę Od społeczeństwa tradycyjnego do nowoczesnego. Demografia i zdrowotność głównych ośrodków miejskich Pomorza Zachodniego $w$ dobie przyśpieszonej industrializacji $i$ urbanizacji $w$ Niemczech (1871-1913), Szczecin 2014. Współautor uhonorowanego wieloma nagrodami, w tym Ministra Nauki i Szkolnictwa Wyższego, Topodemograficznego atlasu gmin Pomorza Zachodniego w 1871 roku (wraz z E. Włodarczykiem, A. Giza, P. Terefenko, Szczecin 2012), który znalazł swoją kontynuację w dziele Atlas gmin Pomorza Zachodniego w 1939 roku. Demografia - społeczeństwo - gospodarka (wraz z A. Giza, E. Włodarczykiem, Szczecin 2017). Od 2015 r. redaktor naczelny czasopisma „Przeszłość Demograficzna Polski”.

Dariusz K. Chojecki - historian and demographer, employee of the Institute of History at the University of Szczecin, associated with the university since 1995. His research interests focus on the population history in the socalled Great German East (eastern provinces of the Prussian state), including Western Pomerania (Provinz Pommern) and Szczecin in the nineteenth century and the first half of the twentieth century. He specialises in the research of demographic processes in the context of social changes taking place in the 
period of the great demographic transition. In his discussion of various phenomena, he tends to combine quantitative and qualitative sources (and methods). In 2002, he defended his doctoral thesis titled Ludność pruskiej prowincji Pomorze $w$ latach 1919-1939. Przemiany $w$ ruchu naturalnym i migracyjnym. In 2014, he received the title of associate professor (dr hab.), with his main achievement being the book Od spoteczeństwa tradycyjnego do nowoczesnego. Demografia i zdrowotność głównych ośrodków miejskich Pomorza Zachodniego $w$ dobie przyśpieszonej industrializacji i urbanizacji w Niemczech (1871-1913), Szczecin 2014. He co-authored Topodemograficzny atlas gmin Pomorza Zachodniego w 1871 roku (co-authored with E. Włodarczyk, A. Giza, P. Terefenko, Szczecin 2012), which received a number of accolades, including the award of the Minister of Science and Higher Education, and was followed by the work Atlas gmin Pomorza Zachodniego w 1939 roku. Demografia - społeczeństwo gospodarka (co-authored with A. Giza, E. Włodarczyk, Szczecin 2017). Since 2015, he has been editor-in-chief of the journal Przeszłość Demograficzna Polski.

E-mail: dariusz.chojecki@usz.edu.pl 